RACAR : Revue d'art canadienne

Canadian Art Review

RACAR

\title{
Entering Art History in the Mid-Nineteenth Century: Félicie d'Ayzac, Anna Jameson and the Legacy of Mme de Staël
}

\section{Adele M. Ernstrom}

Volume 28, 2001-2003

Art History Inside and Outside the University

L’histoire de l'art à l'université et hors de l'université

URI : https://id.erudit.org/iderudit/1069781ar

DOI : https://doi.org/10.7202/1069781ar

Aller au sommaire du numéro

Éditeur(s)

UAAC-AAUC (University Art Association of Canada | Association d'art des universités du Canada)

ISSN

0315-9906 (imprimé)

1918-4778 (numérique)

Découvrir la revue

Citer cet article

Ernstrom, A. M. (2001). Entering Art History in the Mid-Nineteenth Century: Félicie d'Ayzac, Anna Jameson and the Legacy of Mme de Staël. RACAR : Revue d'art canadienne / Canadian Art Review, 28, 29-49.

https://doi.org/10.7202/1069781ar

\section{Résumé de l'article}

Dans son roman, Corinne, ou l'Italie, Germaine de Staël donne à son héroïne le rôle d'une interprète de l'antiquité gréco-romaine et de l'art italien, ce qui semble suggérer que les femmes puissent obtenir un certain accès au champ de l'histoire de l'art. C'est du moins l'affirmation, que nous explorons ici, d'Ellen Moers dans son ouvrage, Literary Women (1976). Plus qu'aucun autre roman rédigé par une femme, Corinne a joui d'une large diffusion au moment de sa parution en 1807. Telle une sibylle, l'héroïne " ressuscite " les monuments de la Rome ancienne d'une manière très persuasive. Son
approche de la peinture de la Renaissance au dix-huitième siècle est marquée par une analyse de son contenu narratif. Cette fiction vivante sous-entendrait que, même sans aucun statut professionnel ou sans appui institutionnel reconnu, une femme pouvait s'adresser à un large public en matière d'art.

Avec l'annulation de toute identité civile pour les femmes sous le Code Napoléon (1804), Germaine de Staël est devenue ce que l'historienne Geneviève Fraisse identifie comme « une figure de référence pour la femme nouvelle ", ajoutant que " référence ne signifie pas modèle ». Dans ce sens nous pourrions la trouver pertinente pour Félicie d’Ayzac (1801-1881), institutrice à la Maison impériale de la Légion d'honneur de Saint-Denis, où elle poursuivit pendant plus de trois décennies l'étude minutieuse de l'iconographie de l'art gothique français. Elle apportait une connaissance approfondie de la littérature patristique et des commentaires médiévaux à ses travaux, comme sa mémoire sur la sculpture des tourelles de Saint-Denis (1847) en fait foi, et dans laquelle elle justifiait la

"monstruosité » des formes hybrides comme une partie nécessaire d’un programme cohérent, ou "monstruosite " des formes étude sur les statues du porche septentrional de Chartres (1849), dans laquelle elle critique A.-N. Didron pour des identifications sans fondements historiques de figures de vertus publiques et privées.

En Angleterre, dans le même esprit que l'héroïne du roman, Anna Jameson (1794-1860) contestait la présomption d'une connaissance de l'art strictement technique ou confinée aux artistes. En écrivaine sans aucune appartenance institutionnelle, elle a utilisé, pendant plus de trente-cinq ans, divers genres d'écriture pour établir le sens de l'art du Moyen Age et de la Renaissance, comme le journal de voyage (1826); la critique interculturelle (1834), similaire à la méthode de Germaine de Staël dans De voyage (1826); la critique interculturelle (1834), similaire à la méthode de Germaine de Staël dans l'Allemagne; le catalogue de collections publiques et privées (1836-44), et, enfin, l'introduction à
l'iconographie chrétienne destinée à un large public et qui lui servait en même temps de compendium (1848-64). Les travaux de Jameson soulèvent divers problèmes : celui de la pertinence du concept de sympathie, lequel dérive de la philosophie des Lumières et surtout de la pensée de madame de Staël, et celui des rapports entre les textes d'amateurs et la littérature érudite. De manière générale, la distinction entre les deux catégories était beaucoup plus souple au dix-neuvième siècle et moins marquée qu'elle ne l'est devenue depuis l'institutionnalisation de la discipline.

Dès le début, les disciplines universitaires ont cherché à définir les paramètres de leur champ d'étude et à établir des « habitus » disciplinaires, un concept de Panofsky que Bourdieu a emprunté et qu'il a modifié par la suite. La définition d'un corpus de l'histoire de l'art impliquait des négociations complexes autour des normes des Beaux-Arts et la possibilité d'une étude systématique des fondements historiques des productions artistiques hors du canon esthétique. Félicie d'Ayzac et Anna Jameson ont toutes deux contribué de façon remarquable à définir le corpus et à développer les méthodes pour le traiter. Pour Félicie d'Ayzac et en général dêur les corpus et à développer les méthodes pour le traiter. Pour Félicie d'Ayzac et en général pour les archéologues français de la période, l'interprétation des monuments gothiques devait se faire à partir des textes médiévaux Quant à elle, Jameson donnait l'exemple en utilisant des sources historiques pertinentes et, en particulier, en puisant dans les légendes populaires des saints. Nous examinons ici avec prudence problème résidait aussi dans les stratégies institutionnelles mises de l'avant par une succession de " grands " hommes.
Tous droits réservés @ C UAAC-AAUC (University Art Association of Canada | Association d'art des universités du Canada), 2004
Ce document est protégé par la loi sur le droit d'auteur. L’utilisation des services d’Érudit (y compris la reproduction) est assujettie à sa politique d'utilisation que vous pouvez consulter en ligne.

https://apropos.erudit.org/fr/usagers/politique-dutilisation/ 


\title{
Entering Art History in the Mid-Nineteenth Century: Félicie d'Ayzac, Anna Jameson and the Legacy of Mme de Staël
}

\author{
ADELE M. ERNSTROM, EMERITA, BISHOP'S UNIVERSITY
}

\section{Résumé}

Dans son roman, Corinne, ou l'Italie, Germaine de Staël donne à son héroïne le rôle d'une interprète de l'antiquité gréco-romaine et de l'art italien, ce qui semble suggérer que les femmes puissent obtenir un certain accès au champ de l'histoire de l'art. C'est du moins l'affirmation, que nous explorons ici, d'Ellen Moers dans son ouvrage, Literary Women (1976). Plus qu'aucun autre roman rédigé par une femme, Corinne a joui d'une large diffusion au moment de sa parution en 1807. Telle une sibylle, l'héroïne « ressuscite » les monuments de la Rome ancienne d'une manière très persuasive. Son approche de la peinture de la Renaissance au dix-huitième siècle est marquée par une analyse de son contenu narratif. Cette fiction vivante sousentendrait que, même sans aucun statut professionnel ou sans appui institutionnel reconnu, une femme pouvait s'adresser à un large public en matière d'art.

Avec l'annulation de toute identité civile pour les femmes sous le Code Napoléon (1804), Germaine de Staël est devenue ce que I'historienne Geneviève Fraisse identifie comme « une figure de référence pour la femme nouvelle », ajoutant que « référence ne signifie pas modèle ». Dans ce sens nous pourrions la trouver pertinente pour Félicie d’Ayzac ( $1801-1881)$, institutrice à la Maison impériale de la Légion d'honneur de Saint-Denis, où elle poursuivit pendant plus de trois décennies I étude minutieuse de l'iconographie de l'art gothique français. Elle apportait une connaissance approfondie de la littérature patristique et des commentaires médiévaux à ses travaux, comme sa mémoire sur la sculpture des tourelles de Saint-Denis (1847) en fait foi, et dans laquelle elle justifiait la "monstruosité » des formes hybrides comme une partie nécessaire d'un programme cohérent, ou encore son étude sur les statues du porche septentrional de Chartres (1849), dans laquelle elle critique A.- N. Didron pour des identifications sans fondements historiques de figures de vertus publiques et privées.

En Angleterre, dans le même esprit que l'héroïne du roman, Anna Jameson (1794-1860) contestait la présomption d'une connaissance de l'art strictement technique ou confinée aux artistes. En écrivaine sans aucune appartenance institutionnelle, elle a utilisé, pendant plus de trente-cinq ans, divers genres d'écriture pour établir le sens de l'art du Moyen Age et de la Renaissance, comme le journal de voyage (1826); la critique interculturelle (1834), similaire à la méthode de Germaine de Staël dans De l'Allemagne; le catalogue de collections publiques et privées ( $1836-44$ ), et, enfin, l'introduction à l'iconographie chrétienne destinée à un large public et qui lui servait en même temps de compendium (1848-64). Les travaux de Jameson soulèvent divers problèmes: celui de la pertinence du concept de sympathie, lequel dérive de la philosophie des Lumières et surtout de la pensée de madame de Staël, et celui des rapports entre les textes d'amateurs et la littérature érudite. De manière générale, la distinction entre les deux catégories était beaucoup plus souple au dixneuvième siècle et moins marquée qu'elle ne l'est devenue depuis l'institutionnalisation de la discipline.

Dès le début, les disciplines universitaires ont cherché à définir les paramètres de leur champ d'étude et à établir des « habitus» disciplinaires, un concept de Panofsky que Bourdieu a emprunté et qu'il a modifié par la suite. La définition d'un corpus de l'histoire de l'art impliquait des négociations complexes autour des normes des Beaux-Arts et la possibilité d'une étude systématique des fondements historiques des productions artistiques hors du canon esthétique. Félicie d'Ayzac et Anna Jameson ont toutes deux contribué de façon remarquable à définir le corpus et à développer les méthodes pour le traiter. Pour Félicie d'Ayzac et en général pour les archéologues français de la période, l'interprétation des monuments gothiques devait se faire à partir des textes médiévaux. Quant à elle, Jameson donnait l'exemple en utilisant des sources historiques pertinentes et, en particulier, en puisant dans les légendes populaires des saints. Nous examinons ici avec prudence de quelle manière leur travail a été ignoré ou même rejeté, puisque nous pensons que le coeur du problème résidait aussi dans les stratégies institutionnelles mises de l'avant par une succession de « grands » hommes.
Cette généalogie de femmes, étant donné notre exil dans la famille du père-mari, nous oublions un peu sa singularité, et même nous sommes amenées à la renier. Essayons de nous situer dans cette généalogie féminine pour conquérir et garder notre identité. N'oublions pas, non plus, que nous avons déjà une histoire, que certaines fermmes, même si c'était difficile culturellement, ont marqué l'histoire et que trop souvent nous ne les connaissons pas.

\section{Luce Irigaray, Sexes et parentés}

\footnotetext{
"The
} he major fashion set by Corinne as tour guide was the opening of the field of art history to women in the days when there were no academic or curatorial posts available to them": so Ellen Moers wrote in her study Literary Women in 1976 of Germaine de Staël's Corinne, ou l'Italie (1807). ' The author of Staël's work is here confounded with the identity of its heroine, as was usual almost from the beginning with Vigée-Lebrun's portrait of Madame de Staël en Corinne (fig. 1). ${ }^{2}$ Moers sought to explore the authorizing presence for women writers of a book that has been seen as both novel and cicerone to the art and antiquities of Italy. Having affirmed that the "major fashion" set by Corinne related to women and art history, Moers undercuts her statement by observing that Staël "was a reluctant tourist in the domain of the plastic arts". 3 She then defines as Staël's 


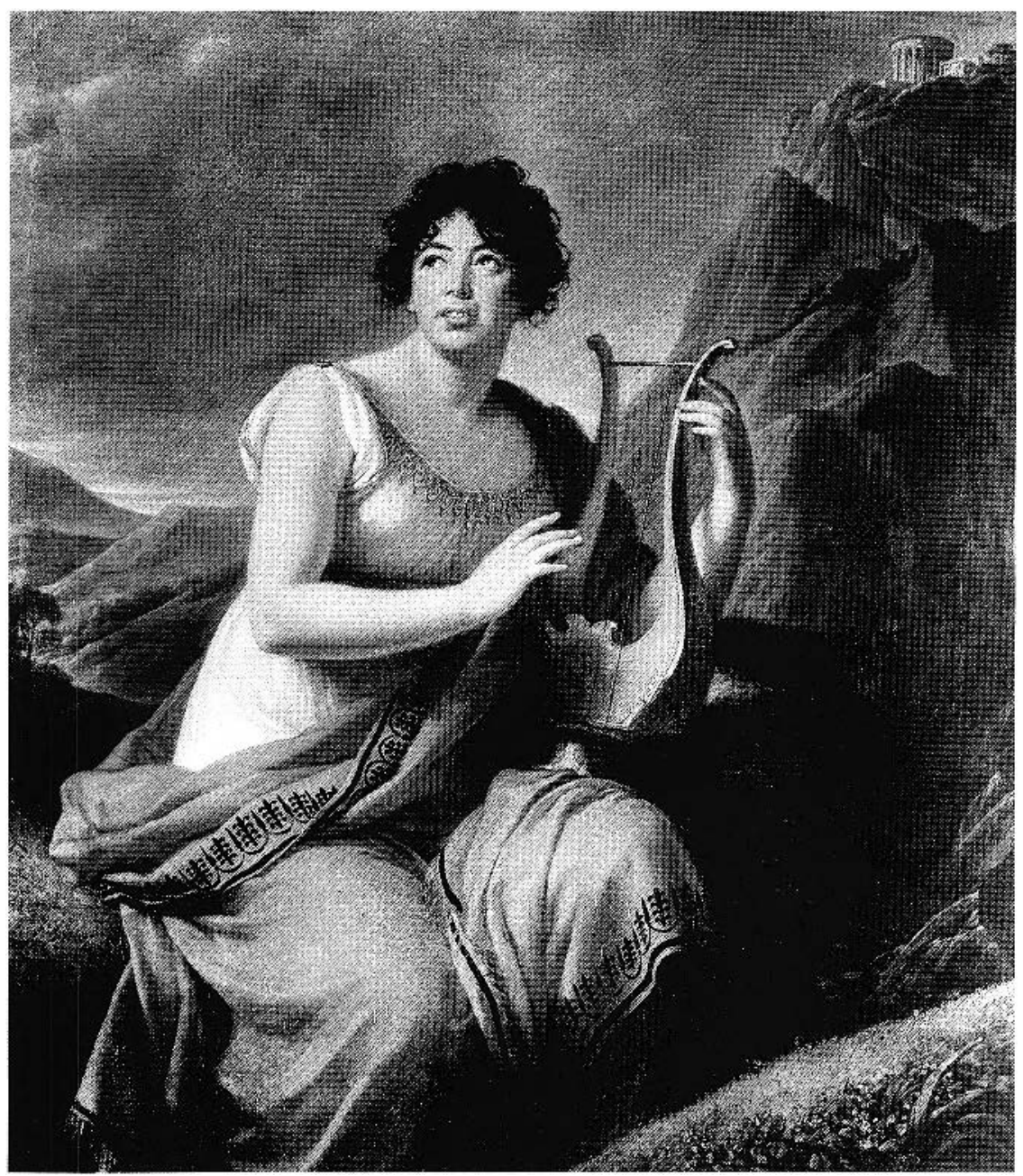

of art could then be considered a "field", or its practice "opened", rather than possibly seized. To assay the basis for Moers's affirmation, it may serve to examine Corinne's framing of the interpretation of art by a woman with a public career, and to look further at the novel's grounding of claims for art's importance in an economy of human values.

An independent woman with a public career in the opening years of the nineteenth century: Staël introduces this unlikely configuration with Corinne's first appearance in the novel. "Corinne au Capitole" evokes an imperial triumph as the heroine is borne in a quadriga to be crowned on the Capitol in Rome in recognition of her prodigious artistic gifts (fig. 2). She is an improvisatrice who also sings, performs in tragedy, dances, draws with grace and invention, improvises poetry and converses brilliantly in ordinary conversation - all with equal distinction. Known only as Corinne, without patronymic, she has named herself after a lyric poet of Greek antiquity; the act followed renunciation of her family name, as the reader learns later in the novel. Her origins and familial ties unaccounted for in Rome, her native element, Corinne is a self-invented woman. This fashioning of an identity contrasts starkly with the constrained locatedness of Delphine, Staël's earlier heroine who, in the novel of that name, is destroyed by tyrannies of social opinion as they applied to women in late

intention an entitlement for women in the field of literary criticism. And yet, it is the quality of presence in monuments of art and architecture, the peculiar immediacy of their witness to history, that is elevated in Corinne. The ruins of Rome "become the subject of the novel", as Marie-Claire Vallois astutely observed. ${ }^{4}$ Persuaded by Corinne, her British admirer Lord Nelvil agrees that the unmediated "érudition" acquired before the monuments of Rome "est bien plus animé que celle qui s'acquiert par les livres: on dirait que l'on fait revivre ce quion découvre, et que le passé reparaît sous la poussière qui l'a enseveli". ${ }^{5}$

On the verge, perhaps, of acknowledging such insistence in the novel, Moers seems to have withdrawn from a track she felt unwilling to pursue; the scope of Literary Women is, after all, hugely wide-ranging. But despite contradictions in her statements on Corinne, linkage of the novel with the opening of art history to women deserves more attention than it has received. This despite reservations about the extent to which the history eighteenth-century France. ${ }^{6}$ In Italy, Corinne affirms, a woman may be acclaimed for her talent, rather than envicd or scorned. Rome's sympathetic climate admits her association with a classical literary reputation and her adoption of the persona of a Sibyl.

Corinne's costume is very much part of this identity. Staël states that she is dressed like the Sibyl of Domenichino, an Indian shawl wrapped around her head, "ses cheveux du plus beau noir" intermingling with its folds (p. 52). She wears a white gown with blue drapery fastened beneath the bust. The outfit, indeed, is neo-classical, while the Indian shawl registers a fashion dating from the last years of the eighteenth century. ${ }^{\text {? }}$ Comparison with the more sedate turban and opulent dress of Domenichino's type for the Sibyl, here exampled by the picture in the Wallace Collection, suggests a limited resemblance (fig. 3). But what counted for Staël was the free appropriation of traditions of inspired female seers of antiquity, for which 
Figure 2. Orrin Smith, Arrivée triomphale de Corinne au Capitole. Engraving after Boulanger, published in Mme de Staël, Corinne, ou l'talie, 2 vols (Paris, 184I), I, 42 (Photo: Bibliothèque nationale de France, Paris).

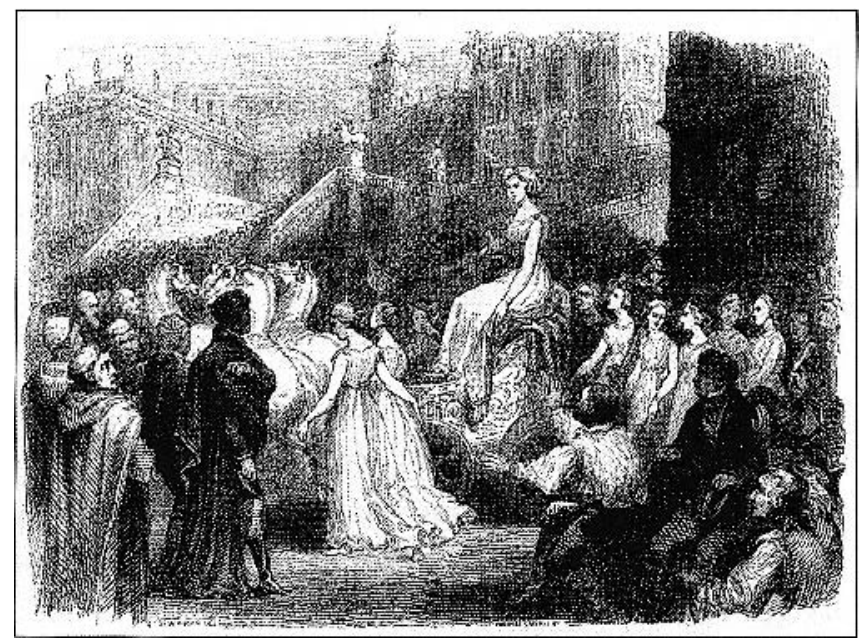

Domenichino's imagery offered elegant, and comparatively recent, confirmation.

Hailed with enthusiasm by the Roman populace, Corinne mounts the steps of the Campidoglio, "ce lieu si fécond en souvenirs" (p. 52) and the seat of Rome's municipal government. In the great hall of what may be inferred to be the Senators' Palace, Corinne is received by the Senator who will crown her, witnessed by Conservators of the Senate, Cardinals, the most distinguished women of the country, men representing the Roman Academy, and part of the crowd that follows the procession. Staël offers some distance on all this in suggesting that, for Lord Nelvil, the coronation of Corinne inspired the kind of interest attached to an adventure imagined by the Renaissance poet Ariosto. But the scene, pivotal to the novel and, arguably, to its reception by women, is multiply determined. Unlike the triumphs of statesmen - or especially, by implication, of generals - Corinne's "char de victoire" costs no one any tears. Staël, who had been banned from Paris by Napoleon after Delphine appeared in 1802 and again the following year,

Figure 3. Domenichino, A Sibyl, ca. 1623-25. Oil on canvas, $79 \times 69 \mathrm{~cm}$. The Wallace Collection, London (Photo: The Wallace Collection, London).

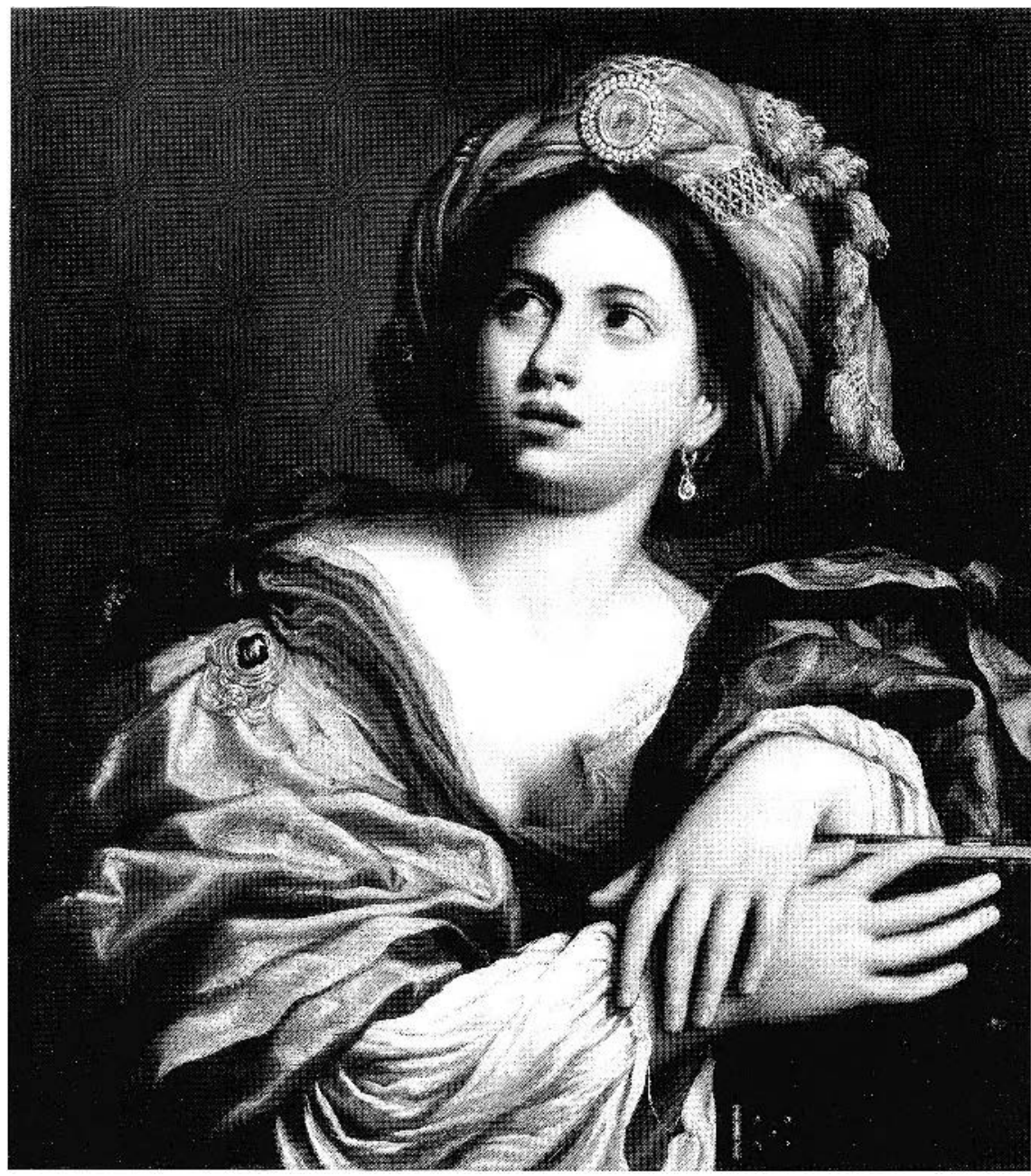
must have conceived this triumph in counterpoint to the coronation of Napoleon in 1804 and, most pointedly, to its celebration by J.-L. David in Le Sacre (fig. 4). David's great machine was completed in 1806-07 while Staël was composing Corinne. Although she can hardly have seen it, given the ban, ${ }^{8}$ she would surely have known of this major public commission through her extensive network in Paris. Notable in the juxtaposition proposed here is that, in preparation for the ceremony in Staël's novel, Corinne kneels on the first step of the dais on which the officiating Senator's chair is placed. In Le Sacre, also known as The Coronation of Josephine, this is exactly the position of the Empress who bends her head while Napoleon holds the crown aloft, leaving open to question whether he will place it on her head or his own. The comparison between Josephine, whose recognition hinges on her role in Napoleon's dynastic ambition, and Corinne, who is honoured in her own right, could not be more telling. Staël here issues a challenge to the principle associated with Napoleon: la carrière ouverte aux talents.

Corinne's talents are various indeed. Her proficiency in vocal music, tragic drama, dance, draughtsmanship, improvisation and 
Figure 4. J.-L. David, Le Sacre (The Consecration of Emperor Napoleon I and Coronation of the Empress Josephine in the Cathedral of Notre-Dame de Paris, 2 December 1804), 1806-07. Oil on canvas, $601 \times 902 \mathrm{~cm}$. Musée du Louvre, Paris (Photo: Réunion des Musées nationaux/Art Resource, New York).

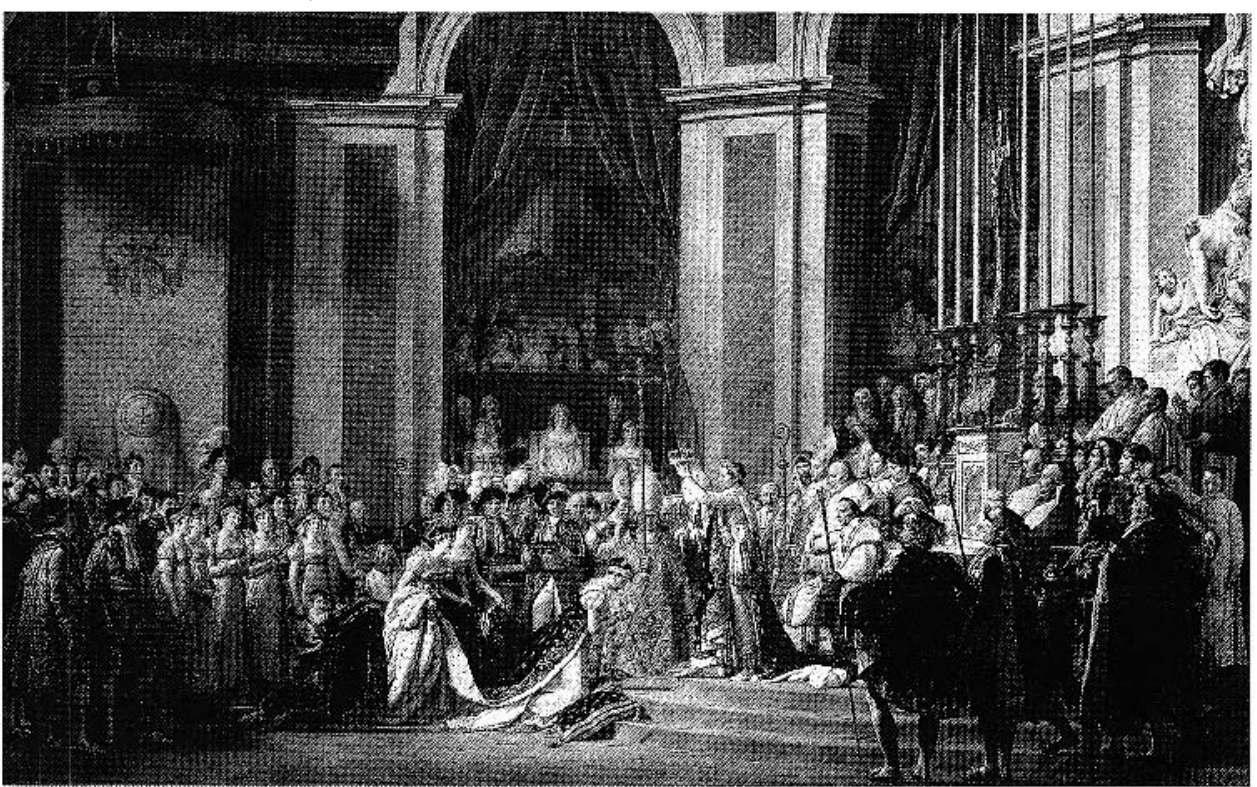

Especially pertinent for Staël, I would suggest, is the centrality of art, and of the imagination, in Schelling's philosophy. Its significance in this sense has been unsuitably discounted on the grounds of Schelling's inattention to specific works of art; he was too little an "Augenmensch", Beat Wyss comments as though visuality or rigorous formal analysis of art were established principles of criticism around $1800 .{ }^{14}$ Schelling in his System of Transcendental Idealism (1800) had posited as infinitely opposed the realms of conscious activity (spirit) and nature; their identity or resolution is effected solely in, or by, the work of art which mediates between intention and unconscious impulses, other-

eloquence announce "la réunion de tous les talents qui captivent l'imagination" (p. 50). If "réunion" of these arts in Corinne implies their original interdependence, Staël's depiction of her performance is far more than an alternative to portrayal of a desk-bound writer, as has been suggested. ${ }^{9}$ A concept of the imagination is central to Staël's aesthetics and, with it, the arts of figuration that engage an image-constructing faculty, rather than the exercise of imitation in the tradition of Aristotle's Poetics. She makes this position explicit in De l'Allemagne (1810), where she affirms that the human soul harbours "des sentiments innés que les objets réels ne satisferont jamais, et c'est à ces sentiments que l'imagination des peintres et des poètes sait donner une forme et une vie". ${ }^{10}$ As has been remarked of Goethe, the contemplation of art for Staël was an imaginative process, rather than one of close visual analysis." She was, of course, widely aware of currents in late eighteenth-century philosophical thought that ennobled the imagination. But most striking are the affinities of her ideas with those of F.W.J. Schelling on the imagination and on art as privileged point of connection between the human spirit and the world of nature.

Staël became acquainted with Schelling's philosophy in Weimar in late $1803-04 .{ }^{12} \mathrm{He}$ had lectured on aesthetics nearby at the University of Jena in winter 1801-03, subsequently moving to Würzburg before Staël's visit to Weimar. But his ideas left a powerful impression in the circles Staël frequented there. Published much later (1859) as The Philosophy of Art from Schelling's notes for the Jena/Würzburg lecture, his text sets forth the importance, and difficulty, of the historical study of art, this "unendlichsten aller Gebiete" (most endless of all fields). ${ }^{13}$ wise inaccessible. ${ }^{15}$ The productive intuition through which art reconciles "an infinite opposition in a finite product" is the imagination. ${ }^{16}$ Staël writes in De l'Allemagne of Schelling's project as one of harmonizing the ideal and the real in "cette harmonie, dont les deux pôles et le centre sont l'image". ${ }^{17}$ For Corinne's role as interpreter of art in Staël's novel, the imaginative faculty is primordial, as it is, according to Schelling, in the realization of the work with which the interpreter engages. His concept of the work issues a challenge to exegesis: "So it is with every true work of art, in that every one of them is capable of being expounded ad infinitum, as though it contained an infinity of purposes, while yet one is never able to say whether this infinity has lain within the artist himself or resides only in the work of art". ${ }^{18}$ Germane to the opening of interpretation is Schelling's rejection of the idea of art as imitation. From another direction than that of Staël's view on its insufficiency to the soul's inner world ("sentiments innés"), Schelling objects that art rather than (contingent) nature creates the standard for judging natural beauty. ${ }^{19}$

To be sure, not all aspects of Schelling's philosophy were equally congenial to Staël's understanding, as her discussion of his ideas in De l'Allemagne attests, ${ }^{20}$ let alone relevant to her fiction. Other dimensions of his work may simply have confirmed, or echoed, prior concerns on her part. Schelling's claim, based on an analogy between art and organic life, that the renewal of art demands a return to first beginnings, could have seconded the motif of origins in a "réunion" of the arts in Corinne and in her appropriation of the Sibyl's persona. Yet, the nostalgia around origins at the turn of the eighteenth century was common currency that Staël would have encountered in 
varied forms. She certainly knew of Emma Hamilton's classical "attitudes", represented in prints after drawings by Friedrich Rehberg, published in 1794, and of the German mime, Henriette Hendel-Schütz, renowned for her impersonation of Niobe. ${ }^{21}$ Mesmerizing for contemporary audiences, as evidenced in the extent to which they were recorded, or interpreted, in prints and other media as well as in verbal accounts, such pantomimic performances seem to have been exclusively a female genre. They were received as though the performer "became" the subject of her impersonation, such as the Vatican Cleopatra or some other ancient statue. Spectators observed what was ostensibly a somatic return to origins, the most unmediated form of such a return that could be imagined. One is reminded of Luce Irigaray's analysis of Freud's Totem and Taboo on "woman's special form of neurosis" as that of "counterfeit or parody of an artistic process", which Irigaray places in the frame of women's exclusion from or "improper' access to representation." 22 The "imFigure 5. Franģois Gérard, Corinne at Cape Miseno (Corinne au Cap Misène), exhibited 1824. Oil on canvas, $256.5 \times 277 \mathrm{~cm}$. Musee des Beaux-arts, Lyon (Photo: Studio Basset, Villeurbanne).

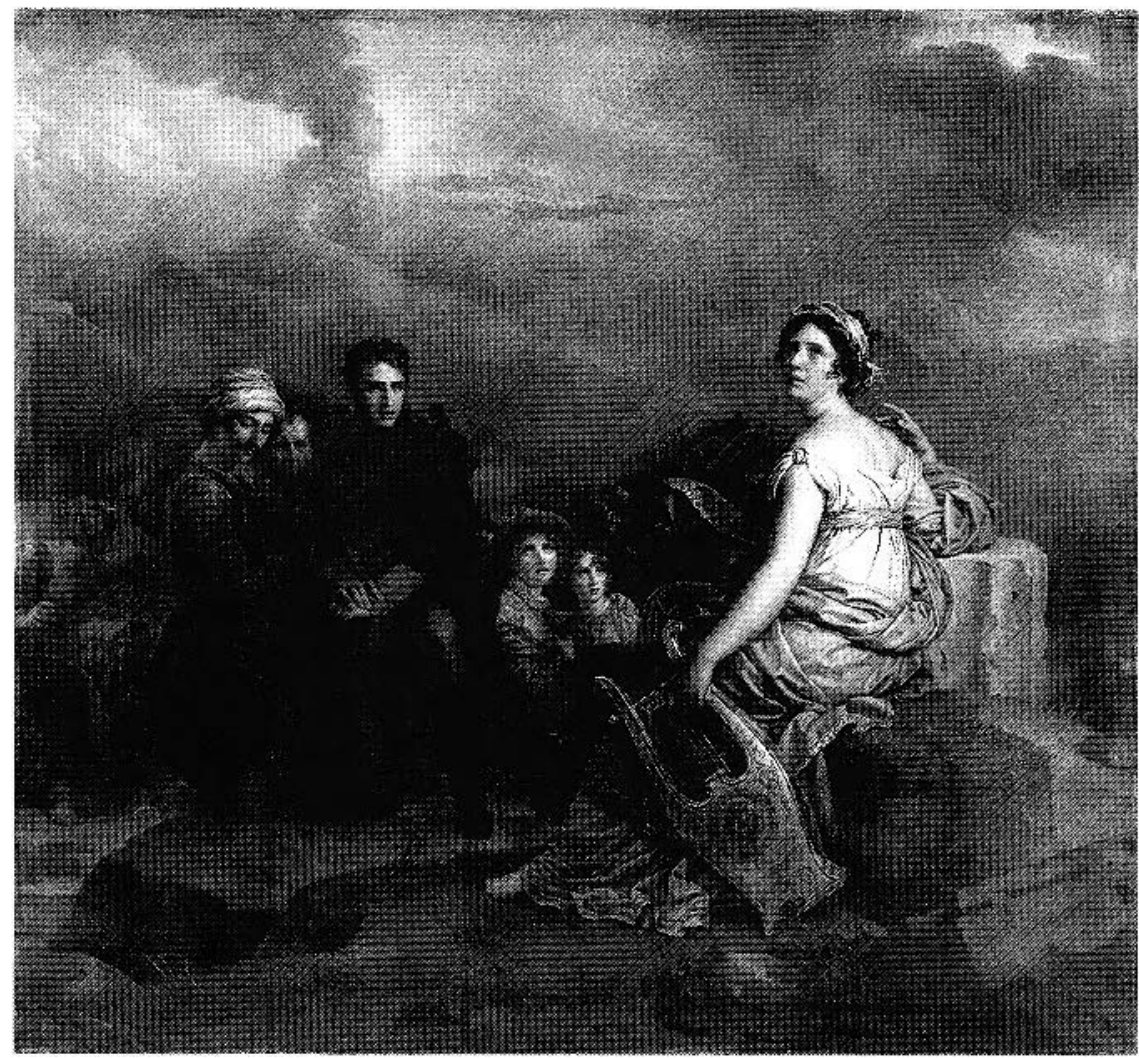
propriety" of women's representation in the performance of classical "attitudes" was accommodated through the disavowal of artfulness as the performer was seen as fusing bodily with the subject of her art. Though Corinne's assumption of the Sibyl's mantle might suggest a comparison, Staël does not have her heroine perform in this way; instead, Staël borrows what suits her: the antiquity of the sibylline tradition, its authority and its voice. In this guise she constructs a contemporary figure whose performances, however "inspired", are clearly in command of their materials.

The significance of a magisterial right to speak claimed in Corinne, and of the sheer confidence attributed to its protagonist, can hardly be overemphasized. At the same time, Staël's personage, though said to be a published writer, delivers all the views we learn of in the novel in spoken form. As improvisatrice she draws on an august, but also quite current, tradition of women's implication in Italian literature, that of many extemporaneous poets and improvisers whose métier, according to Giovanni Carsaniga, was well established by the seventeenth century, though with earlier antecedents. He instantiates for Italy what he calls "women's dominant role in society as oral transmitters of culture". ${ }^{23}$ Staël thus joins in her conception of Corinne's authority what was received as the oracular power of sibylline utterance to a long-acknowledged, yet also contemporary, realm of female improvisation.

How, then, is this authority articulated in what Corinne has to say? In its reach it brooks no restriction on domains of high culture that may be addressed. They encompass the history of civilization, fine arts, literature and music and, in addition, open to exploration the question of national differences in mentality and expression at all social levels. Actual women had, indeed, achieved recognition during the eighteenth century in each of these pursuits excepting, perhaps, the last: a precondition for the assurance Staël ascribes to her heroine. What is new is the novel's imaginary in staging a position for philosophical criticism on such matters by a woman without institutional support for the offering of judgment. The oral modes that Corinne deploys in this sense are threefold. Most Sibyl-like are her public performances evoking in broad strokes the vicissitudes of history. On the occasion of her coronation, she treats "La Gloire et le bonheur de l'Italie". The tragic fates of Agrippina and others associated in life and death with the vicinity of Naples engage her in the performance represented in François Gérard's painting, Corinne at Cape Miseno (fig. 5). ${ }^{24}$ Quite different is the guise of leadership in group debate of themes opening onto the future, as in her handling of Italian literature in relation to the country's cultural and political institutions.

But most apposite to the fine arts is Corinne's application 
Figure 6. Godard, Musée où sont exposés les statues et les tableaux les plus célebres de I'Italie. Engraving after Eugène Laville, published in Mme de Staèl, Corinne, ou I'Italie, 2 vols (Paris, 1841), I, 281 (Photo: Bibliotheque nationale de France, Paris).

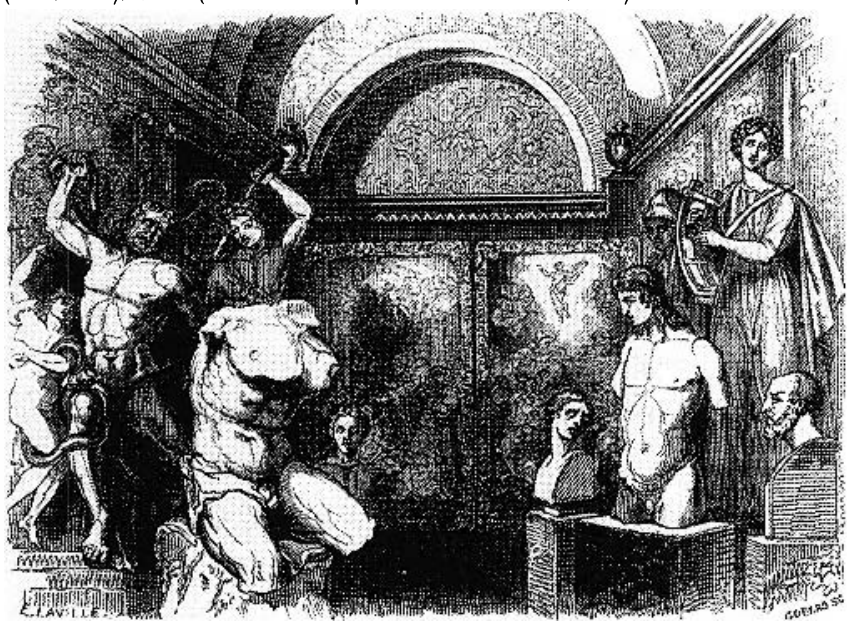

of historical awareness in her voice as cicerone, the function traditionally identified with antiquarian discourse. As tour guide in the novel, she is preeminently an interpreting character, mobilizing interpretation "in the second power", to draw on Naomi Schor's analysis of such activities in fiction. ${ }^{25}$ What especially distinguishes her manner of address from that of the antiquarian in this, as in the other modes, is its direction to a particular audience and an implicit concern for her auditors' symparhy and engagement with her subject.

Corinne's audience in the circuits of Rome and its galleries that she privately conducts is Oswald, Lord Nelvil, who witnessed her triumph on the Capitol. Staël has set the novel in 1795, prior to Napoleon's invasion of the Papal States the following year and his appropriation of art in collections there. Corinne's itineraries can, thus, include works, subsequently removed, for which Rome was famous, while also bypassing military and political issues outside the purpose of the novel (fig. 6).

Oswald is fascinated by Corinne, despite his decidedly English reservations about any "grande publicite" given to the destiny of a woman (p. 49). An ideal student, he is attentive to Corinne's eloquence on the remains of Roman grandeur which she sees as forming a continuum with Renaissance monuments and, indeed, with current work-in-progress, instanced by Canova's tomb for the Archduchess Maria Christina. An excerpt from Corinne's discourse on the Seven Hills of Rome may suggest her interpretive methods and tone of address:

Mount Esquiline was called the Hill of Poets because, as Maecenas' palace was on this hill, Horace, Propertius and Tibullus also had residences there. Not far removed are ruins of the Baths of Titus and of Trajan. It is thought that Raphael took as model those arabesques in the fresco paint- ings of the Baths of Titus. It is also there that the Laocoon group was discovered. The coolness of water gives such a feeling of pleasure in warm countries that one liked to bring together all the pomp of luxury and all the delights of the imagination in places where one bathed. The Romans there exhibited the masterpieces of painting and sculpture. It was by light of lamps that one considered them for it seems, from the construction of the buildings, that daylight never penetrated within and that one wished thus to preserve oneself from those rays of the sun that are so poignant in the south: it is no doubt because of the sensation they produce that the ancients called them the darts of Apollo. One might believe, observing the extreme precautions the ancients took against heat, that the climate was then more scorching than it is now. It was in the Baths of Caracalla that the Farnese Hercules, the Flora and the group of Dirce were placed. Near Ostia in the Baths of Nero the Apollo Belvedere was found. May one not conceive that in looking at this noble figure Nero had felt some generous impulses! ${ }^{26}$

Staël's text is organized around a definition of place in terms of material remains, as in antiquarian inventories of a location. She diverges from their orientation towards "curiosity" and antiquarians' clubbish debate in the appeal to sensibility and imagination with which she sounds the Esquiline Hill for its resonances of association: of literary fame and, by implication, literary patronage; of its architectural and artistic remains; and of what the site has yielded to archaeological discovery. These become materials for philosophical speculation on the usages of the past in a sense enriched by her admiration of Herder, "un poète historien qui touche les ruines de sa baguette", as she characterizes him in De l'Allemagne. ${ }^{27}$ Also pertinent was the richly conjectural guide to Italy of Lalande, whose work she consulted during her Italian sojourn. ${ }^{28}$ As in Herder's philosophy of history and Lalande's critical itinerary, Staël goes beyond the data of historical vestiges to form a synthesis, in her case relating cultural practices to climate. Climate in her view operates as a powerful determinant in the reception of works of art, a force articulated through social institutions instanced in the Baths. The chefs-d'oeuvre of painting and sculpture affect the imagination more profoundly in this setting, it is implied, than in the more solitary experience of a gallery. In Staël's reconstruction, specific conditions of viewing were governed by the exclusion of daylight from the Baths, calling for the use of lamps in contemplating sculpture. All the more likely were such means, she thinks, as the construction suggests a climate formerly more torrid than at present. On the basis of known locations of exhumation and received traditions, she extrapolates for the Farnese Hercules, Flora and Dirce a context of practices in which they worked their effect. It is through such exercise of the 
Figure 7. J.-L. David, Lictors Returning to Brutus the Bodies of his Sons (Licteurs rapportant a Brutus les corps de ses fils), 1789. Oil on canvas, $325 \times 423 \mathrm{~cm}$. Musée du Lourre, Paris (Photo: Réunion des Musèes nationaux/Art Resource, New York).

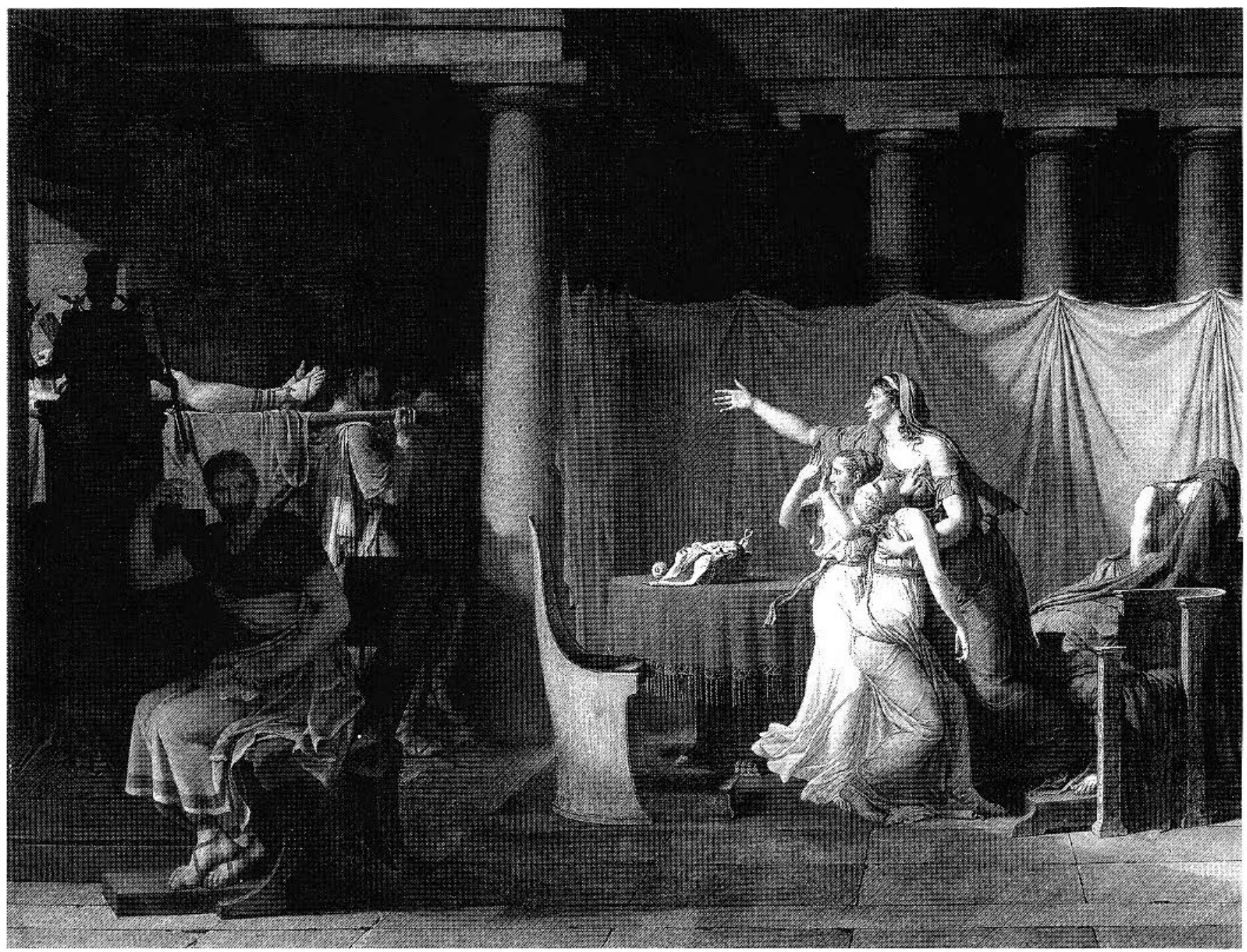

historical imagination, she elsewhere remarks, that we are enabled "to penetrate the genius of time" ("pénétrer le génie du temps", p. 136). That kind of insight cannot be fruitlessly pedantic, as powers of suggestion of those remains could engage artistic emulation in another age: a Raphael might take as model arabesques surviving from Julio-Claudian Rome. Staël conceives ancient statues like the Apollo Belvedere to have been exempla of magnanimity capable of moving such a reprobate as Nero. Her suggestion recalls Winckelmann for whom the nobility of Apollo's look "seems to rise far above" his victory over Python. ${ }^{29}$ But Staël is more concerned than he with what might be construed as the work's ethical efficacy.

That dimension of the criticism attributed to Corinne emerges as well in her ekphrases of pictures. Like those in Vasari's Lives, she emphasizes narrative qualities and the expressive valency of works she describes. As with Vasari and the tradition connected with his work, analyses of composition or arrange- ment and their relation to expression do not appear; Svetlana Alpers points to the absence of a vocabulary for so explaining works of art and to E.R. Curtius' observation that dispositio was given scant attention, in comparison with other rhetorical categories, by ancient theorists. ${ }^{30}$ An ekphrasis by Corinne of a painting in her gallery in Tivoli may suggest Staël's position relative to this legacy and also her divergence from it. Addressing the first in a series of pictures on historical subjects, the exposition seems closely based on a reading of J.-L. David's Lictors Returning to Brutus the Bodies of his Sons (1789, fig. 7), though no artist is named. It goes thus:

The first of the historical pictures represented Brutus in a profound meditation seated at the base of a statue of Rome. In the background, slaves carry his two lifeless sons whom he himsclf has condemned to death, while on the other side of the picture their mother and sisters abandon themsclves 
to despair; the women are fortunately dispensed from exhibiting courage that would make them sacrifice the affections of the heart. The statue of Rome, placed near Brutus, is a beautiful idea: it says everything. Yet how can onc know, without an explanation, that it is the elder Brutus who has just sent his sons to a final punishment? Nonetheless, it is impossible to characterize the event more fully than is done in this picture. One sees in the distance that Rome is still simple, without buildings, without ornamentation, but very great as a country because it can inspire such a sacrifice. ${ }^{31}$

She goes on to remark that Oswald might not have been able to guess the subject had Brutus' name not been attached to the picture and that this uncertainty almost always exists with regard to history painting.

The problem she raises is nonexistent in Vasari, whose selective treatment of narrative usually presupposes his readers' familiarity with historical themes; alternatively, any accompanying inscriptions, texts on scrolls within a work, or known instructions to an artist by patron or agent are considered sufficient. In Corinne, however, the interpreter is assumed responsible for a systematic account of the subject and the meaning. Though her exposition is not elaborate by current standards, she touches on what might be considered the main points: Brutus' despondency beside the statue's symbolic presence; his spatial relationship to the corpses of the sons he has condemned; separation of Brutus from the emotional/moral realm of the women; Rome's severe aspect and greatness as inspiring such a sacrifice. Corinne makes no claims for the painter's particular skills in representation (the statue is "a beautiful idea"), but then her discourse is not directed to artists, either in the immediate fictional context or by extension, as Vasari's was. It is implicitly directed to a wide public for whom the critic considers transparency of meaning an overriding concern. Within the space of interpretations so defined, one separate from the requirement of technical or professional training in art, the possibility of agency is opened to articulate and attentive commentators without institutional authority or other special credentials. And a generic uncertainty in the understanding of history painting calls for this function.

Corinne is likely to have been the most widely circulated novel, perhaps book of any description, to have been published by a woman at the time it appeared in 1807. Simultaneously with its publication in France, the original text and two different English translations with a common title, Corinna, or Italy, came forth in London; in Germany, also in 1807, readers were provided with a translation by Friedrich Schlegel. By 1819 the book had gone through an eighth edition in France. To track in any detail the work's publishing history or its traces across a wide cultural spectrum is beyond the limits of the present discussion. But it is important to signal broadly the power of Staël's novel for an imaginary of the performing woman, equally for the woman of ideas, in the critical years around 1800. The issues at this historical juncture may be briefly suggested. After achieving distinction in salons of the ancien régime, civil status as individuals and, in more popular milieux, political agency in Revolutionary clubs until 1793, women in France lost any identity as citizens under the Civil Code in 1804. The historian Geneviève Fraisse notes that, as they were driven from the public sphere, "Les femmes se battent alors dans l'espace symbolique qui leur reste, l'écriture" - which may be understood as extending to other forms of high culture. ${ }^{32}$ Staël's catalysing presence at this turn was later saluted in 1833 by a Saint-Simonian feminist, Claire Démar, who called her "the woman who through her writings has best supported the strength of our sex, has best protested against our dependency and inferiority". ${ }^{33}$ For Elizabeth Barrett Browning in England at about the same time, Corinne was an "immortal book and deserves to be read three score and ten times - that is, once every year in the age of man.".34

Declarations of this kind by outspoken feminists - the heroine of Barrett Browning's Aurora Leigh (1856) speaks for "artist women" in the mould of Corinne - register what could be said by women specially circumstanced. ${ }^{35}$ From many others there were silences inhabited by the image or example of Corinne. If, as Fraisse affirms, Staël would be "une figure de référence pour la fermme nouvelle", noting that "référence ne veut pas dire modele", the relation might often not be acknowledged in any direct way. ${ }^{36}$

One for whom it may be inferred is Félicie d'Ayzac (180181), "une des premières historiennes de la symbolique chrétienne", according to a 1968 article in the Gazette des Beaux-Arts. ${ }^{37}$ Younger by a generation than Germaine de Staël, Félicie d'Ayzac lived from childhood the civil nullity of women under the Napoleonic Code. Educated at an élite girls' school at SaintDenis established by Napoleon for orphans of deceased French officers, Mlle d'Ayzac, juridically a fille majeure as she remained, continued to teach there until 1852 and then to devote herself more exclusively to the scholarship of medieval art (fig. 8). In what became under the Restoration the Maison royale de la Légion d'honneur, it was a formal requirement of women's employment that they remain single. The stipulation institutionalized what was predicated tragically in the plot of Corinne as a choice for women between love (bonheur) and a cultivated presence in the public realm (gloire): the imperative was seen by Staël as operating through the oppression of social convention for women. Setting aside the problem of whether "glory" may be associated with the vocation of schoolmistress, we need to recall that, in the period of reaction in which Félicie d'Ayzac was born, women's access to the most elementary instruction 
Figure 8. Charles Fichot, drawing and lithograph by, Maison d'Education de la légion d'honneur - Saint-Denis, n.d.; the absence of imperiale or royale in the title would indicate a date during the Second Republic (1848-52), $10.5 \times 17.8 \mathrm{~cm}$. Bibliothèque nationale de France, Paris (Photo: Bibliothèque nationale de France, Paris).

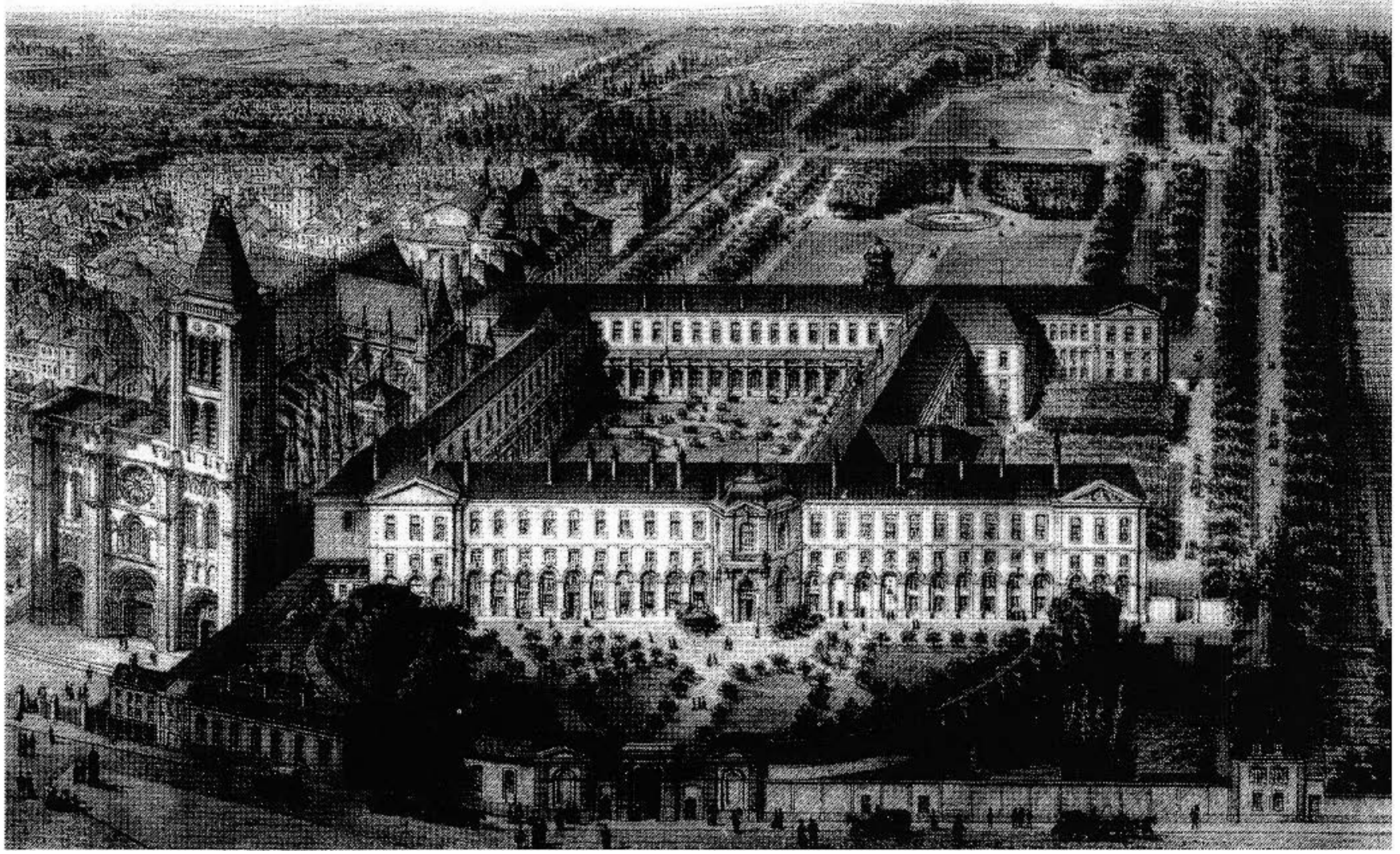

was called into question. Sylvain Maréchal's Projet d'une loi portant défense d'apprendre à lire aux femmes (1801), indeed, insisted that "La place d'une femme n'est point sur les bancs d'une école, encore moins dans une chaire de théologie, de physique ou de droit, comme il s'est vu plus d'une fois à Bologne, en Italie". ${ }^{38}$ How, from existing indications, might we surmise that Félicie d'Ayzac internalized a "choice" between (relative) independence and a life of learning, on the one hand, and on the other, family ties in a régime of enforced dependency for the married woman?

From her book of poems, Soupirs poétiques (1833), an illustration representing a solitary figure seated by an open window, evidently Félicie d'Ayzac, offers some suggestions in conjunction with the poetry (fig. 9). The untitled print faces a poem written in the first person, "Les Regrets". Beneath a statuette of the Virgin and Child, the figure is seated by a child's cradle, in reference to a reluctant exile the speaker has taken from her "bumble hospice" to care for an orphaned brother. She clasps a rosary, but all her attention is absorbed by the view outward through a large open window, from which voluminous drapes have blown or been attached to the side. More faintly defined than the logic of spatial recession would require, the view reveals a field closed by the Church of Saint-Denis from the west and a wing of its convent. The image belongs to a type identified by Lorenz Eitner in which the window is both threshold and barrier, a metaphor of contention between enclosure and a distant object of desire. ${ }^{39}$ Félicie d'Ayzac's flights of longing, her struggle to overcome vain regrets and "longues insomnies", run throughout the Soupirs. In Le Bonheur she evokes music heard at a distance and makes this comparison:

\section{Ainsi, les songes vains de bonheur et d'ivresse \\ Ces songes fugitifs et pleins d'enchantement, \\ Emportés loin de nous, et regrettés sans cesse, \\ A nos yeux fascinés ne brillent qu'un moment. ${ }^{40}$}

These vague yet tormenting dreams merge with a wider sense of historical loss. The subject's relationship with history and its monuments is deftly integrated in the illustration as she gazes towards a structure emblematic not only of personal attachment but also of France's medieval past. 
Figure 9. Untitled and uncredited lithograph, published in Félicie d'Ayzac, Soupirs poètiques (Paris, 1833), facing p. 75 (Photo: Bibliothéque nationale de France, Paris).

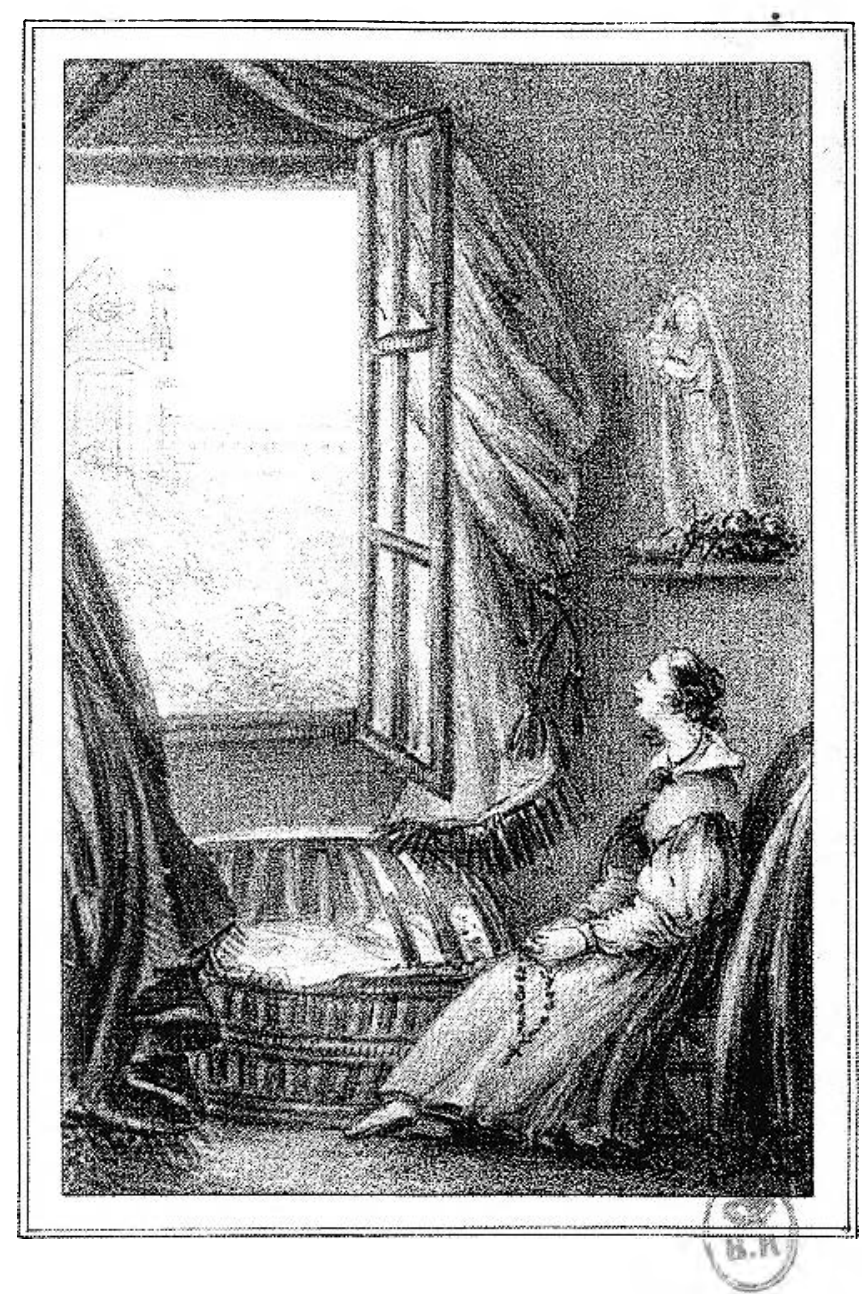

Interpretation of the meanings, and didactic import, of medieval monuments and their imagery was to inform Félicie d'Ayzac's exacting study of the iconography of art in the Middle Ages. In a sense this concern can be related to Staël's attention to the narrative bearing of history painting and the problem of its intelligibility. But a major turn was being prepared in the meantime with valorization of France's artistic patrimony, a shift largely initiated by Alexandre Lenoir's Musée des monuments français with its catalogue (editions 1793-1816) and carried forward in a range of "amateur" efforts that included formation of the Société des antiquaires de Normandie (1824). In 1830 , the July monarchy recognized patrimonial claims on a wide front by instituting a post providing for the inspection of historic monuments. The development gave further impetus to the study of a national, as distinguished from classical, "archaeology" devoted to the country's artistic inheritance. ${ }^{41}$

Apart from government reports, the new field of study took published form in a range of specialist periodicals and monographs that were, nevertheless, concerned to raise public awareness of the meaning, with the historical and aesthetic value, of medieval art. It was in such formats that the work of Félicie d'Ayzac appeared from the mid-1840s through 1886. One of the earliest of these was her Mémoire explicating the symbolic character of architectural sculpture decorating four turrets of the Church of Saint-Denis. Her lengthy article appeared in the Revue générale de l'architecture et des travaux publics (1847-48) and as a separate monograph by the same publisher in 1847.42 César Daly, architect and editor of the Revue, explored by way of introduction some fundamental questions of legitimacy in the assessment of medieval art. These encompassed the problem of "ugliness" in art of the Middle Ages, its symbolic nature and purpose of furthering the moral perfection of humankind, as well as allegorical interpretation authorized by Patristic tradition that was presented as making this art intelligible.

Félicie d'Ayzac states that she had lived twenty years beneath the tourelles of Saint-Denis, without being able to distinguish, at a distance of 38 metres, figures decorating each of four turrets flanking gables of the basilica's south and north transepts. As state-sponsored restoration of the church neared completion in 1845 , she was able to mount scaffolding erected for installation of a metal roof and so examine the sculpture's hybrid forms - part human/part animal and beasts of composite nature. She links the work with popularity in the thirteenth century of hybrid creatures forming what she calls a Zoologie mystique - a corpus drawn from scriptural allegories, medieval commentary, handbooks for lay readers, bestiaries and books of bird lore (Volucraires). ${ }^{43}$ The development is related in turn to late medieval refinement in classifying familial derivations of the seven deadly sins. To students of medieval art, it will be striking that she makes no mention of St Bernard's denunciation in 1125 of "those ridiculous monsters" with their "marvellous and deformed comeliness" in the monastic cloister sculpture at Cluny, or other Cluniac or Benedictine monasteries. ${ }^{44}$ The omission was surely deliberate; Félicie d'Ayzac's project contested assumptions of the capriciousness of medieval art, offering elaborate textual support by which all aspects of the imagery could be seen as justified. It is her premise that a symbolism of hybrid forms is grounded in scripture or commentary upon it, though allowing - more incidentally - that the imagery owed something to "traditions légendaires". 45 Composite creatures become signs resuming in a single form meanings assigned to different species. Moralizing "translation" of such mythical creatures as the Siren and Onocentaur (human bust with ass's body) into theological treatises, and other texts that fixed their meanings permitted an alignment with the seven deadly sins and derivative vices. It is such iniquities, especially those most often attributed to the clergy, hypocrisy and lust, that Félicie d'Ayzac finds epitomized in the figures of Saint-Denis.

As instance of her analysis of the ensemble, we may con- 
Figure 10. P. Fournival, Statues symboliques de la Tourelle Sud-Ouest de L'Eglise. XIlle Siécle, lithograph published in Félicie d'Ayzac, Mémoire sur trente-deux statues symboliques observées dans la haute partie des tourelles de Saint-Denys (Paris, 1847), plate 26 (Photo: Bibliotheque nationale de France, Paris).

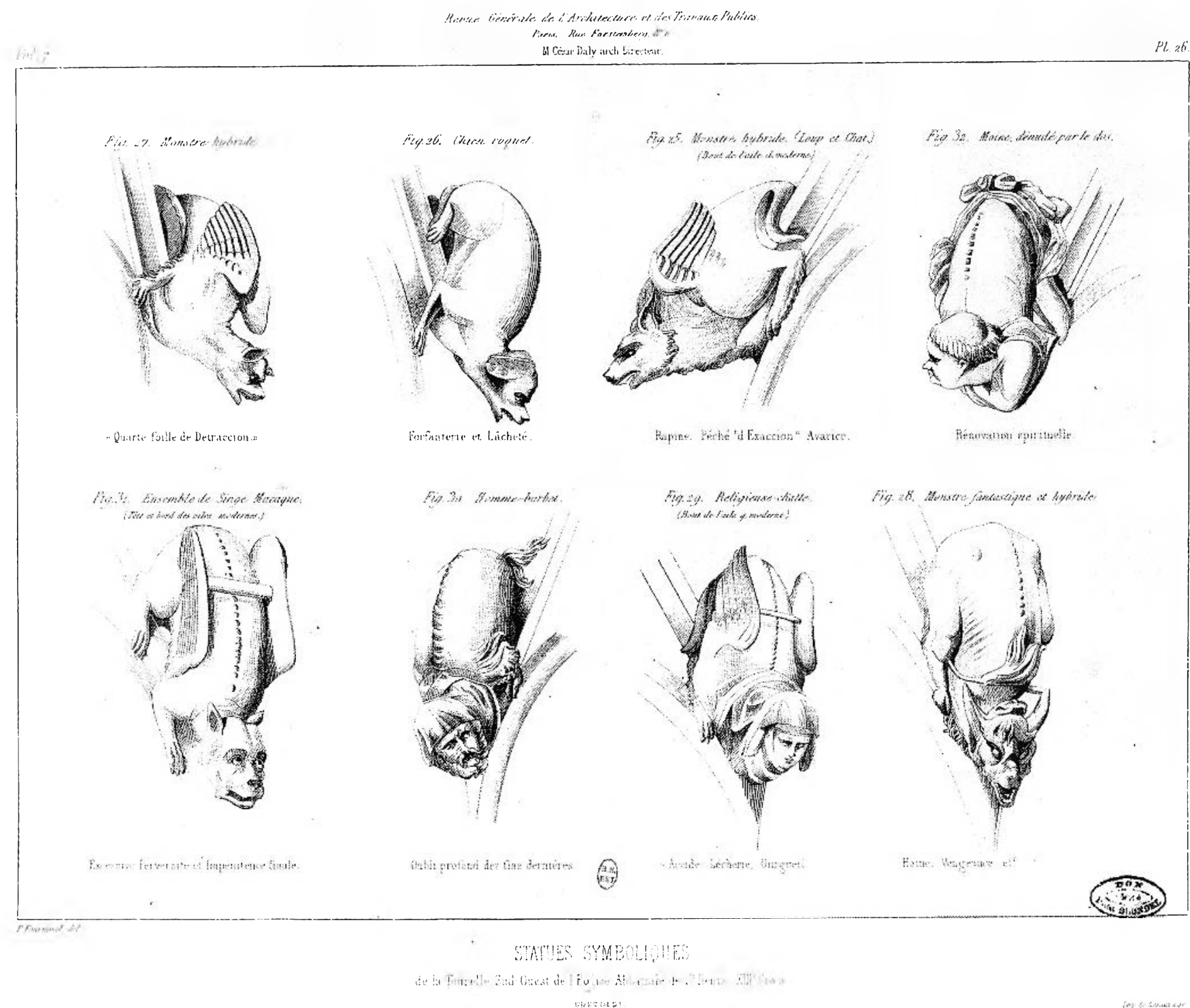

sider the discussion of figures of the southwest turret as portrayed by P. Fournival in lithographic pen, one of several illustrations in the study (fig. 10). Gargoyle-like, these figures incline downward from haunches of the arcade articulating the eightsided turret. Félicie d'Ayzac thinks this group a culmination of the programme, reading according to the figures' numbered sequence which, for whatever reason, does not follow a left to right order in the print. Fig. 25, "Monstre hybride (Loup et Chat)" is, like the others, captioned with reference to its moral nature, "Rapine, Péché 'd'Exaccion.' Avarice", and personifies great prelates. With three others in the series, "Loup et Chat" has wings associated with the pretension to flight without the capacity, an emblem of hypocrisy. From fig. 26, "Chien roquet" (snarling dog), signifying brazen temerity before God, we move to "Monstre bybride", fig. 27; with head and body of a more vigorous dog and tail of a leech, it is a figure of detraction. Most demon-like with its fierce expression and horns is fig. 28, "Monstre fantastique et hybride," possessed of a long tail (always sinister) and a habit of brooding hatred associated with the temperament of a camel. The "Religieuse - Chatte", fig. 29, with female head, claws and impotent wings, stands for cunning, "arme lache des faibles", and related failings. Heloïse may be figured here, Félicie d'Ayzac speculates, in reference to dispersion on Suger's demand in 1129 of the convent at Argenteuil, from which Heloise led a group destined for the Paraclete. But it is curious, she thinks, that Heloïse should be stigmatized; the monks' animus might 
rather have been directed at Abelard who, as member of the order at Saint-Denis, enraged his community by denying the identity of St Denis and Denys the Areopagite. ${ }^{46}$

Joining traits of a short-tailed dog, cat and old man, the somewhat larval form of the "Homme-barbet" (or spaniel), fig. 30 , is said to combine the cat's female cunning with a "malice satanique" ascribed to old age when it has lost merits that might constitute its dignity. Félicie d'Ayzac sees the figure as epitomizing an "oubli profond des fins dernières". Its neighbour on the page, "Ensemble de Singe Macaque", fig. 31, denotes a creature with body of an Asian monkey, wings bolted together like that of the Religieuse and, not shown in the print, a thin, sleek tail like that of a lion. The simian character prevails here in the sense of multiple perversities, chief among them the mockery of God and divine law. Concluding the series is fig. 32, "Moine dénudé par le dos". Leaving behind the sensual destiny symbolized by a dragon's tail and having pronounced his vows, this moine profes turns westwards in recognition of the ends of human life.

In her apology for the ensemble as art, Félicie d'Ayzac invokes criteria of classical aesthetics. Dating from the thirteenth century, the work in her view is that of a single individual, an Italian sculptor well acquainted with ancient art and with the "sources divines de l'art religieux et chretien". ${ }^{47}$ Decorum is respected: the artist displays knowledge and something of genius in conceiving hybrid creatures that are not ridiculous or shocking to the eye. To the strictures of a Charles du Fresnoy whose Art of Painting deplored "Monsters of barbarous birth", ${ }^{48}$ Félicie d'Ayzac replies by implicitly denying heterogeneity; it is simply that we are unaccustomed to seeing figures thus assembled. They have beaury that is farouche, yet ideal in its kind.

This taming discourse may appear strained. Surely the force, to the extent that it may be found in these forms, resides in their transgression? What could be the "ideal" of monstrosity? Du Fresnoy's reference to "barbarous birth" evokes the longue durée of an association of women with monsters in, notably, the birth process by which they are brought into the world. More broadly, the linkage goes back to Aristotelian premises in which the female presents an anomaly relative to a male model as the human norm, premises implicit in the tradition of anatomical illustration by which all functions common to both sexes are epitomized by male figures. ${ }^{49}$ In Félicie d'Ayzac's generation, no social or political question was more fraught than that of implications to be drawn from sexual difference. On it turned the definition of conditions excluding women from the public sphere. This context would seem suggestive for Félicie d'Ayzac's attraction to, as well as her defence of, a subject so inapt to be reconciled with ideas of beauty, and one not centred on a grand, rationalizing system like that of Vincent de Beauvais' Speculum universale. This thirteenth-century encyclo- paedia had been mobilized shortly before to explain the arrangement of statues and effigies decorating medieval churches in the Histoire de Dieu (1843) of A.-N. Didron, Felicie d'Ayzac's contemporary and, in some sense, archaeological colleague. ${ }^{50}$

Didron, indeed, criticized Félicie d'Ayzac's preoccupation with symbolism, while acknowledging the remarkable erudition of her Symbolique des pierres precieuses, ou Tropologie des gemmes. The work appeared in 1846 in the Annales archéologiques, founded by Didron two years earlier, and separately as a monograph..$^{51}$ As in her use of the folkloric bestiaries, she marks a novel direction for medieval "archaeology" in the Pierres précieuses. Despite a paucity of description in medieval texts of the "église matérielle" and the scant vocabulary in scripture for distinctions of colour, Félicie d'Ayzac proposes in this study an understanding of colour symbolism as mediated by the function of precious stones in Old and New Testament contexts. For her tropology of gems, that is the use of scripture to extrapolate a moral interpretation beyond literal meaning, she curns to medieval commentators such as St Bruno of Asti, who elaborated an equivalence of Christian virtues with the colours and diaphaneity of stained glass windows without historical subjects. The discussion traces an alignment between on the one hand Moses' fashioning of the High Priest's shoulder-pieces and breastplate with four rows of gems, each specified, and engraved with names of the children of Israel (Exodus 28: 9-21) and, on the other, twelve precious stones cited in Revelation (21:18) as garnishing walls and foundations of the heavenly Jerusalem. Now, the correspondence between these lists is not complete: ten only figure in both: sardius, topaz, emerald, sapphire, jacinth, amethyst, jasper, onyx, sardonyx and beryl. But in addition to translation problems, there are complications in the classification of gems. Their association with virtues seems much clearer on the Christian than on the Old Testament side, where importance attaches to the engraving of names on the stones. As inconclusive as this must necessarily be, the imaginative quality of the inquiry, which in another period might have plotted its claims differently, deserves the most serious respect.

It was her methodological audacity and the branching fluidity perhaps intrinsic to the interpretation of colour symbolism that gave rise to Didron's reservations. Commenting on the blue-green beryl, for example, she quoted in translation St Bruno's characterization of the "aigue-marine, couleur de l'eau frappée des rayons du soleil" and assimilated the stone with virtues of sacred heroism. ${ }^{52}$ But though she cited authorities for the mystique of precious stones and of colour, Didron not only objected to some of her ideas but to those of a number of her sources, "qui sont des rêveries souvent": Innocent III, Hugues de Saint-Victor, Cornelius-a-Lapide and others. Félicie d'Ayzac drew on strains of Christian mysticism, probably enriched by the Jewish Cabala or tradition positing God's second and secret 
revelation to Moses in giving him the Law. ${ }^{53}$ God's exacting prescriptions to Moses in Exodus for arrangement of the High Priest's breastplate could well be encompassed by this central premise. In correlating meanings attributed to the mention of gems in the Old Testament passage with the imagery of precious stones in Revelation, the study does not suggest supersession of the Era under Law as in Christian typological symbolism. The inquiry seems rather to assume principles held in common by both religious faiths, as in Frances Yates's characterization of the project of Ramon Lull and other Christian students of the Cabala in the Middle Ages. ${ }^{54}$

From treatment of the "virtues" of precious stones to iconography of the weasel in a study published a year before her death in 1881, Félicie d'Ayzac's scholarship was sustained over more than three decades in a period critical for the historiography of medieval art. Besides the works noted, her production included an institutional history of the Abbey of Saint-Denis, a study in an implicitly Staëlian framework comparing medieval Italian churches with those of northern Europe, investigations of the sculpture of Chartres and further chapters of a Zoologie mystique. ${ }^{55}$ Her Statues du porche septentrionale de Chartres prompts some final comments on her understanding of art historical method. In this monograph she takes issue with the interpretation of personified Virtues on archivolts of the Cathedral's north porch as formulated by Didron for a governmentcommissioned monograph on Chartres. ${ }^{56} \mathrm{He}$ there argued that on the innermost of three archivolts in the porch's east bay were represented the Virtues "de l'homme privé", with domestic Virtues arrayed on the next; the social "virtus du citoyen" he identified on the outermost archivolt, projected as it were into the public space. ${ }^{57}$ But the Middle Ages at no point framed such a category as public virtues, Félicie d'Ayzac contended, elaborating grounds based principally on St Anselm for seeing the figures as Celestial Beatitudes. She flatly rejected the claim for domestic Virtues, proposing instead that the twelve female figures represented contrasts between the active and the contemplative life. Her recognition that such questions had to be adjudicated with reference to pertinent historical sources here collided with a nineteenth-century template dichotomizing private and public spheres.

And yet, I would suggest, the very rigour she brought to interpreting medieval concepts of the Virtues and Vices had grounds not only in her integrity as an historian of art but also in a contemporary condition. It arose from the anxious compact formed after the Revolution by which women were excluded from the public sphere: "les hommes font les lois et les femmes font les moeurs" in the succinct formulation of one citoyen Thérémin, writing in $1799 .{ }^{58}$ Mme de Staël had influentially supported this partition, while insisting on women's right to education as necessarily accompanying a responsibility for social mores. ${ }^{59}$
The engagement of Félicie d'Ayzac with medieval definition and representation of the Virtues and Vices may be understood at one level as linked with gender-inflected prescriptions in French society of the nineteenth century. At the same time, it was productive for the defrichement of an important dimension of Christian iconography more than half a century before art history was recognized as a university discipline in France. In the present issue of RACAR, Lyne Therrien cites Emile Mâle as saying in 1894 that, from the standpoint of university recognition, scholars had for sixty years studied the national art of France in vain (pp. 53-54). But Mâle himself was the legatee of that wealth of research and interpretation. He carried it into the university in consecrated publications informed by familiarity with the work of Félicie d'Ayzac and other earlier "archaeologists". Though he would claim in the preface to L'Art religieux $d u$ XIIIe siecle en France (1898) that there had hitherto been no book on his subject, a reading of Mâle's work informed by acquaintance with that of his predecessors will throw into relief the extent of his indebtedness. Respecting Félicie d'Ayzac, his arguments around her understanding of symbolism and, what was never theorized in the period, the limits of its interpretation, attest to his engagement with her scholarship. So do his objections, consonant with Mâle's dismissal of popular sources generally, to the importance she gave to the bestiaries. ${ }^{60}$ But the mixed and insufficient character of his acknowledgments may better be deferred to more general consideration of the effects of institutionalization in this regard. Before taking up that question, I would introduce another nineteenth-century figure active outside a then nonexistent university discipline, one whose career presents both analogies and differences from those of Félicie d'Ayzac, as do the relations of each to the legacy of Mme de Staël.

Clara Thomas, the Canadian biographer of Anna Jameson (17941860 ), first called attention to her subject's veneration of Germaine de Staël. ${ }^{61}$ That fervour of admiration Thomas found traceable in Jameson's letters and throughout her published work. We may discern it also in the earliest known portrait of Anna Murphy, as she then was at age sixteen, three years after the publication of Staël's novel. Translated as an engraving from a miniature (fig. 11), the work by Anna's father Denis Murphy hints earnestly at the sybilline example of Corinne in the subject's raised glance and visionary act of pointing heavenwards; represented awkwardly, the gesture is borrowed from such august prototypes as the Plato figure in Raphael's School of Athens and Leonardo's St John the Baptist. Later, in 1822, Gérard deployed a similarly lifted gaze and upward gesturing forearm in his Corinne at Cape Miseno (fig. 5).

Essentially self-taught, Anna Murphy's education was very much less regular than that of her contemporary at Saint-Denis, notably in the grounding in Latin that Félicie d'Ayzac mobi- 
Figure II. H. Adlard, Anna Murphy, engraving after miniature by Denis Murphy, published as frontispiece to Gerardine Macpherson, Memoirs of the Life of Anna Jameson (London, 1878). Author's copy (Photo: Grant Simeon, Lennoxville).

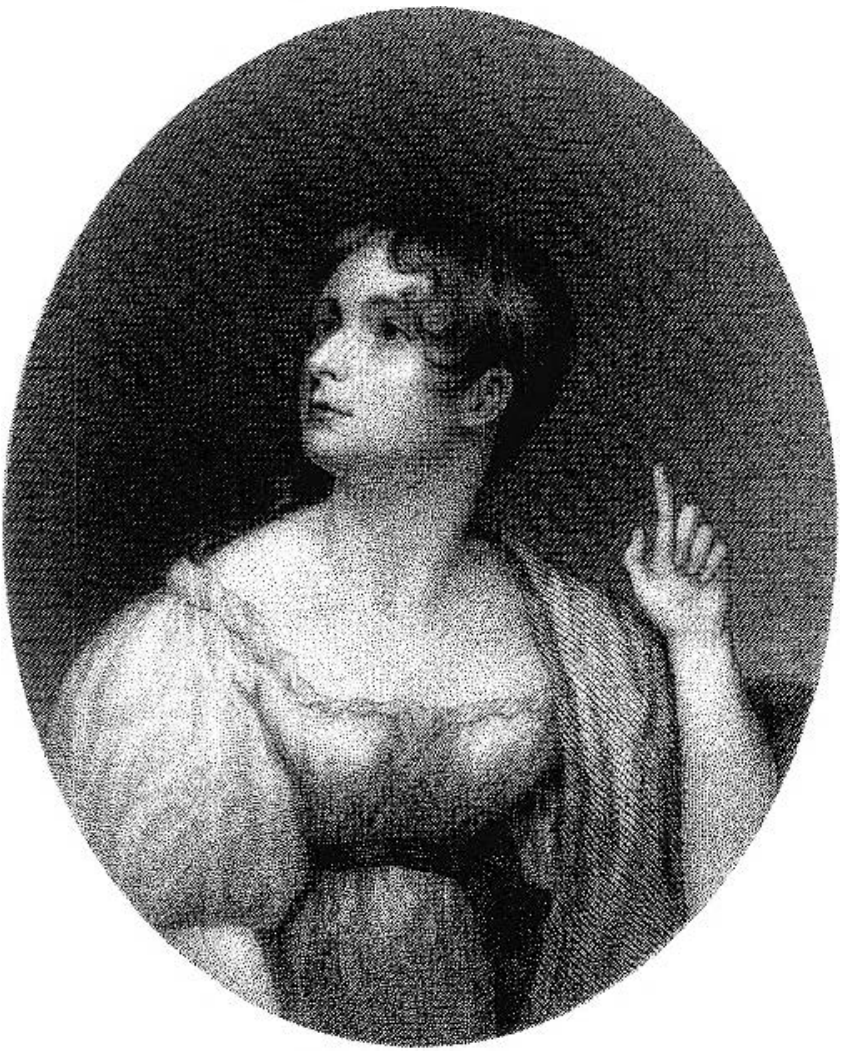

lized in her research. ${ }^{62}$ Denis and Johanna Murphy were, however, culturally ambitious and encouraged the self-cultivation of their eldest daughter. At the time Denis Murphy executed her portrait, the family resided in Pall Mall, London, a neighbourhood that from the late eighteenth century attracted artists and writers. Among them were the miniature painters Maria and Richard Cosway. It is highly probable that the latter's success and his reputedly lavish payment as Principal Painter to the Prince of Wales stimulated Denis Murphy's professional hopes as a miniaturist. Indeed, Murphy was in 1810 named Painter in Enamel to Charlotte, daughter of the Prince of Wales and his estranged wife, Caroline of Brunswick. But he received nothing for his commission to make miniature copies of Lely portraits in the royal collection (the "Windsor Beauties") before Charlotte's death in 1817, or thereafter from her widower, Prince Leopold. Representative of repeated disappointments in Murphy's career, this signal reverse figured in straitened family circumstances framing the aspirations of Anna Murphy. Through youth, marriage in 1825 to Robert Jameson and formal separation from him after 1838, she nevertheless imagined for herself a path that might be a version of that of Corinne. Foremost for her, as for so many of her generation, were claims to be made for Germaine de Staël's scope of intellect. In summing up the reflections of a lifetime, Anna Jameson later cited with approval the refusal of
Sir James Mackintosh to locate Staël within such "feminine" categories as letter writing: "the philosophy and eloquence of Madame de Staël are above the distinctions of sex", she quotes him as stating. ${ }^{63}$

Such affirmations held weight in the contestation over female intellect that, though not identical in form, was as fierce in Britain as in contemporary France. The stature of Germaine de Staël as a woman of ideas also had special implications for advancement of an authority to speak, or write, about art. In addressing art as an "amateur", in parallel with Corinne as interpreter, Jameson confronted the received understanding that knowledge of art was essentially technical and competence to pronounce on it the province of artists. This tradition was particularly tenacious in England. As late as mid-century, Charles Eastlake's status as a painter was crucial for his appointment as Director of the National Gallery in 1855, even if administrative experience and connoisseurial skill - not now seen as altogether guaranteed by artistic practice - were additionally required.

Anna Jameson (as she became) ventured to write on art in a diary she says was never meant for publication. This kind of disavowal accompanies countless works by women writers, variously marking compliance with expectations of female modesty and anguishing uncertainty over the works' reception. Conditions of female authorship, not to mention such legal constraints as a husband's right to his wife's earnings, contradicted assumptions of the self-consistent growth of the subject that Valerie Sanders has traced as a convention in men's life stories in the nineteenth century. ${ }^{64}$ To suggest that Staël represented an ideal for Jameson cannot be taken as predictive of a vocation, let alone of one scarcely foreseeable when professionalization as now understood was undefined. The idea of Corinne interacted rather with choices or determinants in other registers. It was on the strength of an Italian tour in 1821-22 as governess to a monied family that Jameson anonymously published $A$ Lady's Diary, reissued shortly after in 1826 as The Diary of an Ennuyée. ${ }^{65}$ Self-presentation in this work as a Corinne figure who travels independently doubles as masque for the reduced class identity associated with service as a paid governess. Class-based depreciation of Jameson's work would, indeed, be a constant throughout her life and beyond. ${ }^{66}$ In any event, the Ennuyee modestly but firmly assumes a warrant to record her own education in art; the book is almost a Bildungsroman in that sense, stretching to a degree limitations of the travel diary form. Its heroine tours ruins on the Esquiline, returning to consult the Roma antica of Famiano Nardini (p. 165), wonders at the meaning of Titian's Sacred and Profane Love in the Borghese Gallery ("Why does Profane Love wear gloves?", p. 133) and, like Lord Nelvil and Corinne, discusses in juxtaposition Raphael's Transfiguration and Domenichino's Last Communion of St Jerome in the Vatican (pp. 167-69), which appear in the illustration to Corinne (fig. 
6). What is exceptional is the quality of Jameson's engagement, the determination to answer questions she has set for herself; there is, for example, the "half an hour [she spent] looking at the picture called the Cumaean Sibyl of Domenichino", in the Borghese Gallery, becoming "more and more convinced that it is a Saint Cecilia and not a Sibyl" (p. 137). Here she addressed the difficulty of musical attributes for a Sibyl figure, let alone for the Cumaean as traditionally specified. ${ }^{67}$ She saw the question as consequential for grasping the sense of the work.

In entering the marketplace for publication in the $1820 \mathrm{~s}$ and 1830s, Anna Jameson, like any unsponsored or uncommissioned writer, acted as an individual agent, while facing dismissals reserved for women, such as the recently coined "writeress". Her address in negotiating this cultural minefield has been incisively analysed by Judith Johnston, who notes that Jameson would have outclassed most of her competitors "if poverty alone was a literary qualification". 68 Yet, her nonfictional writing, explicitly directed to female readers through the mid-1830s, marks a gain in assurance by that time. A heightened sense of entitlement characterizes Jameson's Visits and Sketches at Home and Abroad (1834), a work initiated by experience of a German tour with her father in 1829. An opening dialogue in Visits and Sketches between two characters, Alda and Medon, offers an implicit tribute to Germaine de Staël's De l'Allemagne when Medon suggests it is the part of "every feeling, well educated, generous, and truly refined woman, who travels ... to aid in the interfusion of the gentler sympathies, to speed the interchange of art and literature from pole to pole ..." ${ }^{69}$ The first account of German art and art institutions for a British public, Visits and Sketches gives greater attention to the visual or plastic arts than Staël had done in her epochal work.

While appealing to women readers, Visits and Sketches also served to establish Jameson's authority on art, as witnessed by her commission to write an introduction to the catalogue of a major private collection in London. ${ }^{70}$ In 1836 the merchant and banker W.G. Coesvelt offered his ninety pictures, almost entirely Italian, to the British government for a reputed $£ 40,000$. In relating the refusal of this offer, Jameson implicitly criticizes a failure of public policy: "even in the lowest sense of the word, fine pictures are part of the riches of a country", she states. ${ }^{71}$ Remarkably enough, the catalogue preserves all the received attributions while Jameson's introduction performs a triage, distinguishing in each instance justified ascriptions from specious claims - of four "Raphaels", notably, only the Alba Madonna remains. Her part in the Coesvelt catalogue may be seen as preparation for work on her monumental catalogues of the following decade: the Handbook to the Public Galleries of Art in and near London (1842) and her Companion to the Most Celebrated Private Galleries of Art in London (1844).

Before undertaking those massive projects, however, she contributed a substantial introduction to Peter Paul Rubens, His Life and Genius (1840), the translation of an essay by the German art historian, G.F. Waagen. ${ }^{72}$ Originally published outside an art historical framework, in a Historisches Taschenbuch in Leipzig in 1833, Waagen's text was directed to a cultivated readership in history - heirs, we may surmise, to an educational legacy like that of Göttingen. Addressing an undifferentiated British public, Jameson holds up as exemplary the high seriousness in art criticism long familiar in Germany, pointing to Waagen's view that works of art bear the profound impress of an individual mind. The position is placed in diametric counter to Reynolds' assurance that all may be gained in art by study and adherence to the rules. However exhausted and open to criticism the concept of romantic genius may be a century and a half later, its application then to a historical figure counted towards investing attention to art with intellectual gravity. The original context of Waagen's publication, indeed, suggests his argument's pertinence for cultivated Germans. In the crosscultural role she had rehearsed in Visits and Sketches, Jameson invites her readers to sympathize with the particular direction of Rubens's mind and the "abounding fancy" of his achievement in various branches. At the same time, she allows for reservations of taste; there are distinctions of register to make in the act of judgment. ${ }^{73}$

The exercise of, and inducement to, sympathy figures in Jameson's authorial posture and in her work at a conceptual level. There was surely a link with the thematic of sympathy evoked by Staël as a quality of Corinne's voice and her appeal to an audience. For both, a common source can be traced in Enlightenment formulations on sympathy or "fellow feeling" as constitutive of human sociability in the widest sense. Opening with a chapter titled "Of Sympathy", Adam Smith's Theory of Moral Sentiments (1759) makes this dimension of feeling central to the exercise of ethical behaviour. Smith's moral philosophy was extended in the early nineteenth century by Francis Jeffrey to an engagement of sympathy in the aesthetic response, which he saw as grounded in shared social emotions. ${ }^{74}$ Jameson's affinities with this line of thought appear in her assumption of a prevailing capacity on the part of readers to grasp imaginatively, by way of sympathy, the peculiarities and also coherence of an artist's intelligence through the artist's work. Her far more ambitious Sacred and Legendary Art of 1848 makes no appeal to social empathy on behalf of individual artists; it rather offers an invitation by way of sympathy to enter into historically remote mentalities productive of "legends" that shaped art in the Christian tradition. Jameson's rhetorical practice disavows advanced qualifications for herself: the book "has been written for those who are, like myself, unlearned", less from a wish to instruct than "to share with others those pleasurable associations, those ever new and ever various aspects of character and sentiment, as 
exhibited in Art, which have been a source of such vivid enjoyment to myself". ${ }^{75}$ Jameson's (unjustified) disclaimer seeks to relieve discomfort on the part of those unacquainted with art, while presenting the subject in its most appealing light.

The notion of sympathy and of orienting texts towards the widest possible audience raises questions relative to the "popularization" of art history and its corollary, originality of content - both for "popular" texts and those assumed by a prior judgment to be originary. There is a problem of registers of education or taste that may be assumed or explicitly addressed. Another relates to the condition of the mid-nineteenth-century reading public, or publics, and what may be premised of reader's access to imagery in whatever form. With respect to taste, Jameson assumes no necessary limitation controlling that which may be presented. Where she could not herself provide illustrations for her texts, she appeals to her audience's possible familiarity with works in Britain or to engravings and evaluates their relative merits. The working-class readers to whom she addressed her illustrated articles on Italian painters in the Penny Magazine from 1843 to 1845 would, it is supposed, be as receptive to discussion of the work of Maso Finiguerra or Ghirlandaio as to the catchpenny prints to which they usually had access (fig. 12).$^{76} \mathrm{~A}$ recent essay characterizes Jameson as a critic, rather than an art historian concerned with art in the dimension of history, who catered to a middle-brow level of taste. ${ }^{77}$ But this is to affix formulations of cultural hierarchy arising in the U.S. around 1900, when a "high-brow"/"lowbrow" opposition deriving from phrenology became current, to a context in which it is inappropriate. Education of the public in art in the early and middle decades of the nineteenth century presented a comparatively open field, or frontier, incommensurate with conditions in fully industrialized societies a century or more later. Jameson, and some others, saw this education as a mission, not as an occasion to dilute her subject. Preoccupied as she was with writing in an accessible style, she firmly rejected the populist axioms of contemporaries such as Allan Cunningham who valued art to the extent that it is immediately intelligible to people in general; it is never that easy, she affirms. ${ }^{78}$

To speak of the popularization of art history in this setting is questionable from several points of view. There was no corpus of disciplinary knowledge in Britain at the time that could support the exercise of vulgarization that this model implies no established scholarship like that available to such a project as Kenneth Clark's television series, Civilisation, in 1969. In the German-speaking countries where art history was in process of development, the distinction between designedly accessible, and specialist, writing was, none the less, quite fluid. We have seen that Waagen's Rubens appeared first in the widely attractive format of a Taschenbuch. Franz Kugler's Handbuch der Kunstgeschichte (1842) was destined for the broadest readership
Figure 12. Maso Finiguerra, The Coronation of the Virgin, wood-engraving after 1452 impression on paper from silver vessel before niello inlay, published in Anna Jameson, Memoirs of the Early Italian Painters, and of the Progress of Painting in Italy, from Cimabue to Bassano, 2 vols in I (London, 1845), 173. Author's copy (Photo: Grant Siméon, Lennoxville).

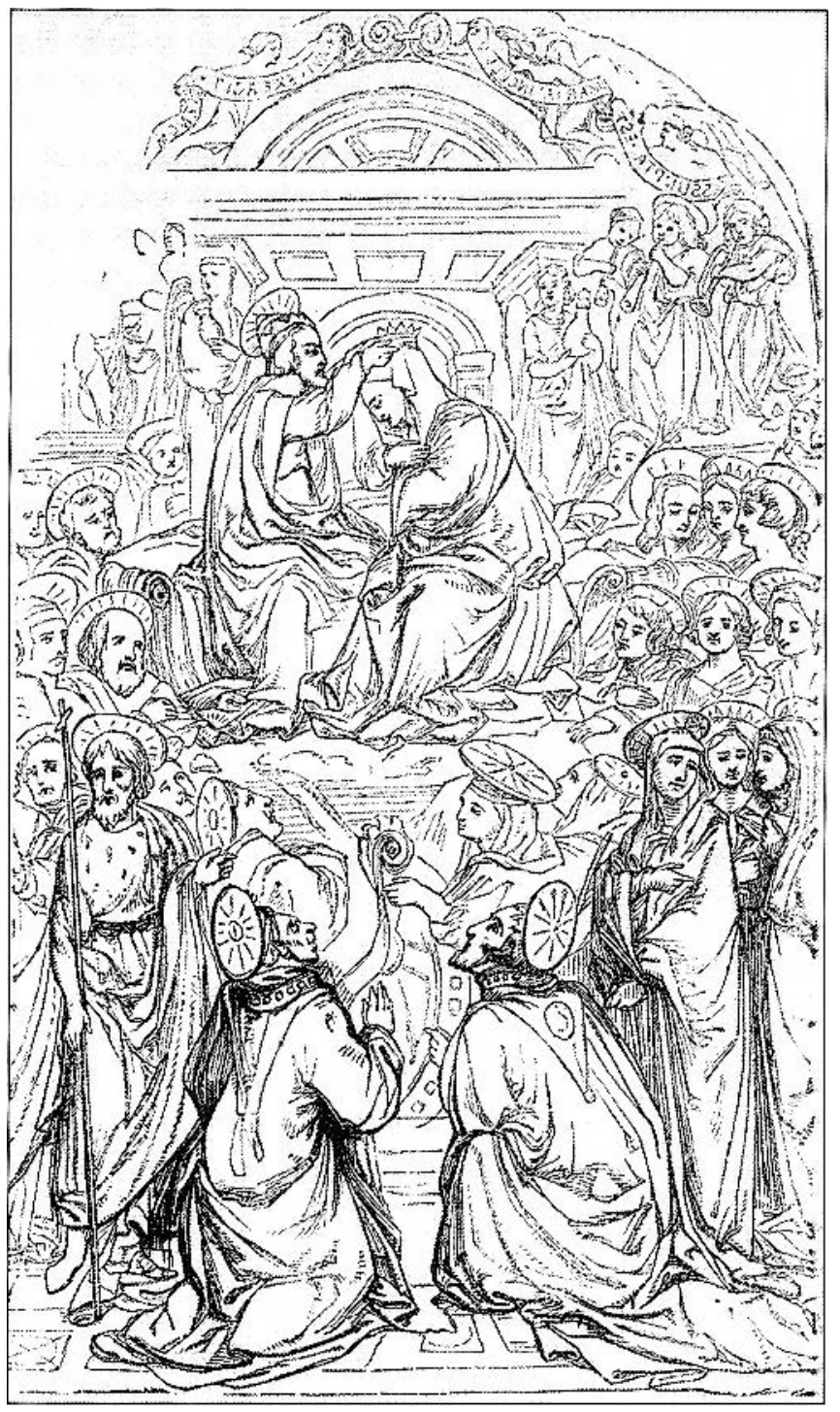

obtainable, as was Jacob Burckhardt's Cicerone (1855). Yet, no one would think to suggest that these publications were not serious. It was by a remarkable feat of transcultural interpretation that Jameson made acceptable to an English-speaking audience principles of research and, where pertinent to her projects, specific findings in the work of a Waagen, Kugler or C.F. Rumohr.

Her magnum opus, Sacred and Legendary Art and its sequels, locates art in its relation to history through the prism of Christian iconography. ${ }^{79}$ Like the scholarship of Félicie d'Ayzac, Jameson's "series" is grounded in sources historically pertinent for the understanding of medieval, and of Renaissance, imagery, though she relies more extensively on such legendary material as Jacopo da Voragine's Legenda Aurea. This tetralogy, as it be- 
came, was conceived to draw in the widest imaginable reaches of the book-buying, or borrowing, public. Its aims were vindicated in the extent to which Jameson's books became necessary points of reference for their subject, remaining in print well into the twentieth century. The 1998 Introduction to Iconography of Roelof van Straten advises prospective students that "these volumes still provide some of the best explanations in English of Christian themes depicted in the fine arts". ${ }^{80}$

Deceased in 1817, Germaine de Staël could scarcely have envisaged the scale of audiences available to publishing Corinnes in the mid-nineteenth century, as in the tens of thousands introduced to art history by Jameson's essays in the Penny Magazine. Yet, the author of Corinne's destiny who, Simone Balayé remarks, "a tant souffert de sa condition de femme" and whose expiring heroine addresses a Deity she believes will not reject "le tribut des talents", might have foreseen the suffering of women who seized the new opportunities. ${ }^{81}$ Staël's incarnation of the woman of ideas as a Sibyl seems metamorphosed into another form of wise woman in a posthumous bust of Anna Jameson executed by John Gibson in 1862 (fig 13). Commissioned by a group of subscribers headed by Susan Horner, the portrait merges Roman gravitas with gentle mobility in the features; a matronly quality, not stressed or sentimentalized, is suggested by a cap peaked over the forehead beneath a classical mantle. An inscription reads in part: "She threw new light on the Christian legends which inspired the painters and sculptors of the past ... [and] in later years she roused public attention to the sufferings of educated women, vainly endeavoring to earn a competency ..." 82 Thus was she seen by contemporaries, principally women but certainly also the sculptor, who honoured in her the wisdom wrought from a lifetime of struggle and productive work.

"A genealogy of values," Michel Foucault wrote in "Nietzsche, Genealogy, History," an essay of 1971, "will cultivate the details and accidents that accompany every beginning; it will be scrupulously attentive to their petty malice; it will await their emergence, once unmasked, as the face of the other." 83 The beginnings of disciplines within academic institutions strenuously seek to codify and legitimate values relative to their definition of a field. They do so with reference to what has already been constituted as a disciplinary habitus - the concept was adopted by Pierre Bourdieu from Panofsky's publication on Suger and Saint-Denis and his Gothic Architecture and Scholasticism - that is, a disposition or posture that entails definition of the field's subjects of study. ${ }^{84}$ For art history, the defining of a corpus involved complex negotiations around standards of value enshrined in the "fine arts" and the eligibility for systematic (as against antiquarian) study on historical grounds of artefacts falling outside received canons of beauty. We have seen the engagement of this process in Félicie d'Ayzac's defense, against a long tradition of classical aesthetics, of hybrid forms on the tourelles of SaintDenis. It is centrally germane that her apology joins a close description of an aspect of the monument with an interpretation of its symbolic meaning. In other respects she addresses dimensions of medieval art, difficult to accept at the time (if not also problematic today), by exploring tendencies of Christian mysticism relating to the art as it may have been understood in its own time.

From another direction, the Jameson/Waagen publication on Rubens works towards construction of an art historical corpus through claims for the idiosyncrasy of "genius", which Waagen attempted to reconcile with the condition of Netherlandish painting in the early seventeenth century. Both Jameson and Waagen contended in their texts against serious reservations of taste, their own and evidently those of their public. On a far wider scale, Jameson's Sacred and Legendary Art legitimates for study a vast range of productions from "Greek Angels" in mosaic in the Cathedral of Monreale to Velasquez' painting in the Prado of St Anthony visiting Paul the Hermit. ${ }^{85}$ Against assumptions of beauty, then more often found in Murillo, or what seemed neglect of minimal expectations of drawing in the Angels, her work demarcates a terrain justified by imagery shaping an imaginary of Christian belief central to Western civilization.

The definition of "field" in art history proceeded also in the register of method. With Félicie d'Ayzac and mid-nineteenth-century French "archaeology" generally, the interpretation of Gothic monuments in their relation to medieval texts was absolutely primordial for the convergence of the discipline. Differences as to how this principle should be applied occurred both before and after institutionalization, but the privileging of the word over the image on the analogy of the Cathedral as sacred book persisted until very recently; questioning of this premise has awaited the influence of post-structuralist critique. ${ }^{86}$

Unlike Félicie d'Ayzac's corpus, that of Jameson was not anchored in the claims of patrimony, itself an historical concept that held primacy in France. Yet, her method was similar, broadly speaking, in its reliance on historically appropriate source material. A divergence, still within general considerations of the definition of field methodologically, may be found in her turn to a wide range of demotic traditions she found embodied in legends of the saints. Yet, Jameson's sense of the integrity, so to speak, of the image vis-à-vis the historically understood word is noteworthy within the entire range of iconographic literature.

In the essay cited above, Foucault asserts that "Humanity does not gradually progress from combat to combat until it arrives at universal reciprocity, where the rule of law finally replaces warfare; humanity installs each of its violences in a system of rules and thus proceeds from domination to domina- 
Figure 13. John Gibson, Portrait Bust of Anna Jameson, 1862. Marble, height $60 \mathrm{~cm}$. The National Portrait Gallery, London (Photo: The National Portrait Gallery, London).

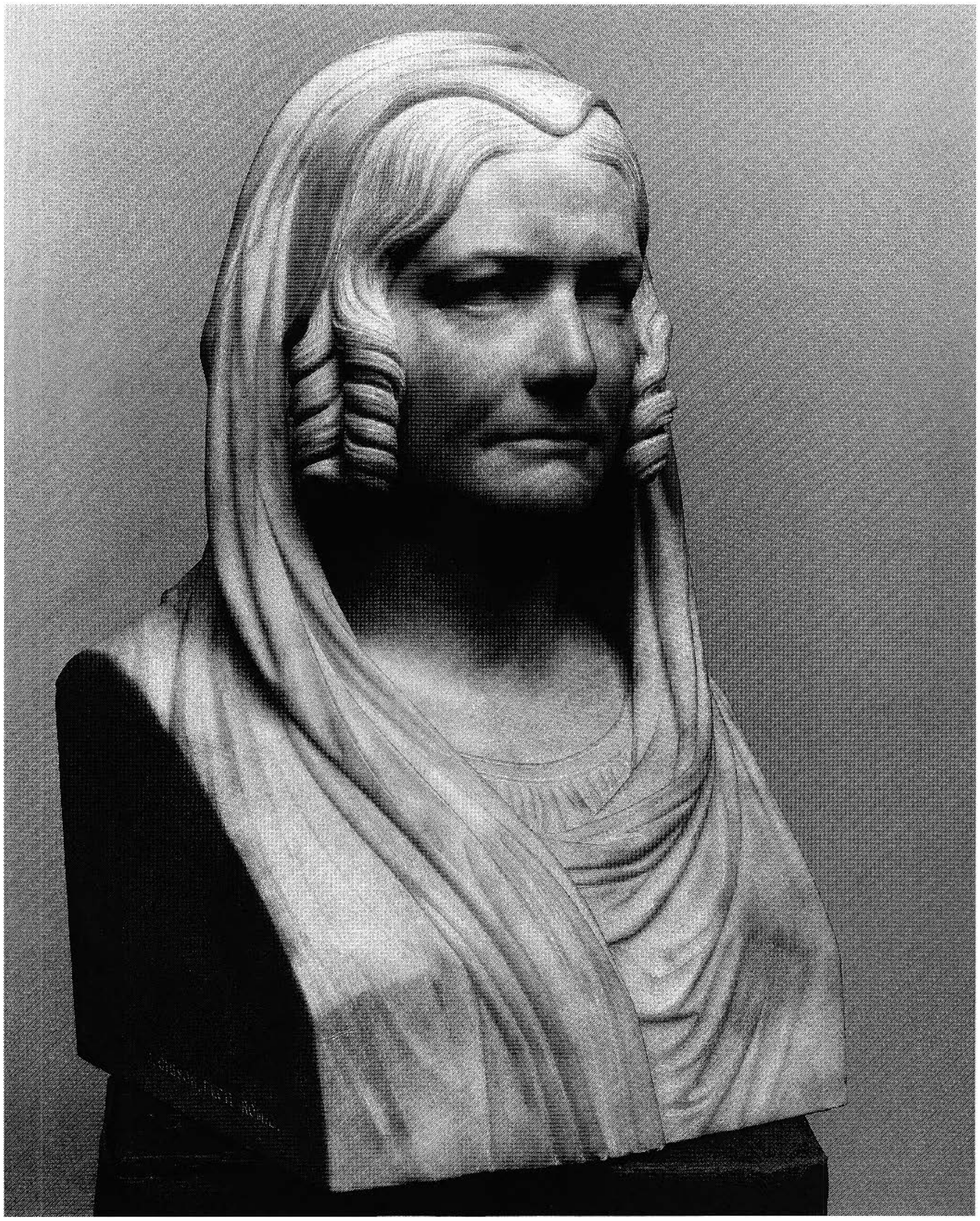


tion." ${ }^{87}$ This might seem a heavy and unduly bellicose observation to apply to the process of institutionalization. Yet, the installation of art history in universities and museums, while making possible many unquestionable advances, imposed a particular régime. It has been one with corporative interests that entailed refusals of recognition, or active depreciation, of the efforts of the uncredentialled, without which emergence of a formally constituted field could not have occurred. In this regard, the granting or withholding of acknowledgment in Mâle's L'Art religieux du XIIIe siècle en France is particularly instructive; his claim for this work as noted earlier, that "un travail de ce genre n'existait pas encore chez nous" is true in the sense that a synthesis of this scope had not previously been produced. ${ }^{88}$ What is at least equally true, but not stated, is that the book we know in English as The Gothic Image could not have been produced without the enormous labour that preceding researchers had effected. Within the many instances in which he agrees, or takes issue, with his predecessors on particular points, there is a gendered inflection among his notices of the work of Félicie d'Ayzac. In connection with what he considered her over-interpretation of the "Porte rouge" of Notre-Dame in Paris, he stated in a sententious non sequitur that "Le symbolisme tient assez de place dans l'art du moyen age pour qu'il n'y ait pas lieu d'acceuillir les rêveries des interprètes modernes" ${ }^{89}$ He leaves unexplained the alleged superfluity of "modern interpretation", the necessary function of nineteenth-century archaeologists with respect to their material. But more, characterizing her concern for symbolism as rêveries is a totalizing judgment linked with various period terms for female inconsequence of mind.

Recourse by scholars to Anna Jameson's works has been in inverse proportion to explicit acknowledgment of her contributions. The American art historian, Madlyn Kahr, informed me in 1975 that she regularly referred to Jameson in her work on Renaissance and Baroque iconography. Yet, as a student of Panofsky she found no mention of her publications in the extensive bibliography for his seminars in iconology. ${ }^{90} \mathrm{My}$ former thesis adviser, the late Jerrold Ziff, remembered in 2000 that, as a beginning graduate student at Harvard, he was introduced to Jameson's writings by Millard Meiss. ${ }^{91}$ Published acknowledgment, however, remains rare, though that pattern has shifted some in the past twenty-five years with the citing of Jameson in connection with specific points of interpretation. What has not changed at all is the omission from histories of art history of any account of women in the field before the late twentieth century; Udo Kultermann's History of Art History (1993) and Donald Preziosi's The Art of Art History (1998) are representative in this regard. Anomalous in comparison with challenges to the writing out of women artists from histories of art, this phenomenon may be partially explained by an assumption on the part of women art historians that women contributed nothing of sig- nificance before their own recent entry on the scene. Yet, a more central factor is likely to be a teleology of institutionalization understood as carried forward by a succession of "great" men. Surely, it is time for a more critical approach in which it may become possible to attend to the emergence of art history, unmasked, as the face of the other.

\section{Acknowledgement}

I would like to acknowledge the assistance of library staff at Bishop's and McGill Universities, the British Library, the Bibliothèque nationale de France and to curators of the Cabinet des estampes, Paris. My thanks as well to the anonymous reviewer of this article, to Cheryl Porter for secretarial support, to Marc Kaltenbach for strategic assistance and to Serge and Gwendolyn Trottein for hospitality in Paris.

\section{Notes}

1 Ellen Moers, Literary Women (New York, 1976), 187.

2 Vigée-Lebrun's portrait may well have been decisive in establishing or confirming the identification. Staël originally thought of having her heroine painted with the features of her friend, Mme Récamier. See Simone Balayé, "Corinne et ses illustrateurs," Versailles, Revue des Sociétés française, suisse et belge des amis de Versailles, etc., no. 27 (2ième trimestre, 1966), 16-25; and the interpretation of the portrait in Mary D. Sheriff, The Exceptional Woman: Elisabeth VigéeLebrun and the Cultural Politics of Art (Chicago, 1996), 247-61.

3 Moers, Literary Women, 188.

4 Marie-Claire Vallois, "Old Idols, New Subject: Germaine de Staël and Romanticism," John Gavin, trans., in Germaine de Staël: Crossing the Borders, eds, Madelyn Gutwirth, Avriel Goldberger and Karyna Szmurlo (New Brunswick, N.J., 1991), 86.

5 Germaine de Staël, Corinne, ou l'Italie, ed. Simone Balayé (Paris, 1985), 122. Further references to this edition are included in text of the article.

6 Germaine de Staël, Delphine, ed. Béatrice Didier, 2 vols (Paris, 2000). Originally published 1802 .

7 Yvonne Bézard, Madame de Staël d'après ses portraits (Paris et Neuchâtel, 1938), 38.

8 Nor later when it was exhibited at the Salon in 1809. For the circumstances of Staël's life (1766-1817), see the outline in Staël, Corinne, 595-602.

9 Moers, Literary Women, 185.

10 Germaine de Staël, De l'Allemagne, ed. Simone Balayé, 2 vols (Paris, 1968), II, 162.

11 John Gage, ed. and trans., Goethe on Art (Berkeley and Los Angeles, 1989), xv.

12 Jean Gibelin, L'Esthétique de Schelling et l'Allemagne de Madame de Staël (Paris, 1934), ix.

13 F.W.J. Schelling, Philosophie der Kunst (Darmstadt, 1980), 311.

14 Beat Wyss, "Der letzte Homer: Zum philosophischen Ursprung der Kunstgeschichte im deutschen Idealismus" in Kunst und Kunsttheorie, eds, Peter Ganz et al. (Wiesbaden, 1991), 236. 
15 F.W.J. Schelling, System of Transcendental Idealism, trans., Peter Heath (Charlottesville, 1978), 225-27.

16 Schelling, System of Transcendental Idealism, 230.

17 Staël, De l'Allemagne, II, 149.

18 Schelling, System of Transcendental Idealism, 225.

19 Schelling, System of Transcendental Idealism, 227.

20 Staël, De l'Allemagne, II, 149-51.

21 Friedrich Rehberg, Drawings faithfully copied from Nature at Naples and with permission dedicated to the Right Honourable Sir William Hamilton ... (Rome, 1794), engraved title-page and twelve etchings after Rehberg by Tommaso Piroli. Lady Hamilton served as model for Corinne according to Geneviève Gennari, Le Premier Voyage de Madame de Staël en Italie et la genèse de Corinne (Paris, 1947), 145 ff. For an account of the career of Hendel-Schütz, professional dancer, actress and mime, see Kirsten Gram Holmström, Monodrama, Attitudes, Tableaux Vivants: Some Trends of Theatrical Fashion 1770-1815 (Uppsala, 1967), 181-208.

22 Luce Irigaray, Speculum of the other Woman, trans., Gillian C. Gill (Ithaca, N.Y., 1985), 125, 124.

23 Peter Brand and Lino Pertile, eds, The Cambridge History of Italian Literature (Cambridge, 1996), 404.

24 But see the interpretation of this picture as representing the end of Corinne's creative life, as against its celebration by Vigée-Lebrun, in Janis Bergmann-Carton, The Woman of Letters in French Art, 1830-1848 (New Haven and I.ondon, 1995), 173-75.

25 Naomi Schor, Reading in Detail: Aesthetics and the Feminine (New York and London, 1987), 122. Schor proposes a taxonomy of interpreting characters, widespread in modern fiction, so as to reflect on the author's relationship with an "interpretant", his or her "specular image".

26 Staël, Corinne, 120, translation by author. Staël's archaeological information is up to date. Maecenas' Villa was joined by Nero to his Domus Aurea. In AD 80, 'Titus built on foundations of the latter Baths that were enlarged by Domitian, Trajan and others. Largely destroyed in the period at which Staell wrote, the remnants of these Baths were cleared in 1813 so as to leave what is now almost entirely the remains of Nero's construction. In her day, location of the Laocoon's discovery was identificd as the "House of Titus" on the Esquiline: Carlo Fea, Miscellanea filologica (Rome, 1790), I, 329. The Farnese Hercules was traditionally thought to have becn found in the Baths of Caracalla and the Farnese Flora, evidently the "Flora" to which Staël refers, believed to have been found with it. The Dirce group, also known as "Fable of Dirce" and "Farnese Bull," is more definitely known to have been found in the Baths of Caracalla. All three are in the Museo Nazionale, Naples. On traditions concerning these works, see F. Haskell and N. Penny, Taste and the Antique (New Haven and London, 1981).

27 Staël, De l'Allemagne, II, 63.

28 Joseph-Jérome Le François de Lalande, Voyage d'un François en Italie, Fait dans les Années $1765 \& 1766,8$ vols (Venice and Paris, 1769).

29 J.J. Winckelmann, The History of Ancient Art, trans., G. Henry Lodge, 2 vols (Boston, 1880), II, 313.

30 Svetlana Leontief Alpers, "Ekphrasis and Aesthetic Attitudes in
Vasari's Lives," Journal of the Warburg and Courtauld Institutes, XXIII (1960), 193 and, especially, n. 14 referring to E.R. Curtius, European Literature and the Latin Middle Ages (New York, 1953), 71.

31 Staël, Corinne, 232, translation by author.

32 Geneviève Fraisse, Muse de la Raison: Démocratie et exclusion des femmes en France (Paris, 1995), 8.

33 As cited in translation in Claire Goldberg Moses and Leslie Wahl Rabine, Feminism, Socialism, and French Romanticism (Bloomington and Indianapolis, 1993), 195.

34 Barbara P. McCarthy, ed., Elizabeth Barrett to Mr. Boyd: Unpublished Letters of Elizabeth Barrett to Hugh Stuart Boyd (London, 1955), 176.

35 Elizabeth Barrett Browning, Aurora Leigh and Other Poems, intro. Cora Kaplan (London, 1978), Bk III, line 407.

36 Fraisse, Muse de la Raison, 194, 214.

37 Anne Prache, "Félicie d'Ayzac: Une des premières historiennes de la symbolique chrétienne," Gazette des Beaux-Arts, I.XXII (octobre 1978), 145-50.

38 As cited in Fraisse, Muse de la Raison, 57.

39 Lorenz Eitner, "The Open Window and the Storm-tossed Boat: An Essay in the Iconography of Romanticism, "Art Bulletin, XXXVII (1955), 281-90.

40 Félicie d'Ayzac, Soupirs poétiques (Paris, 1833), 43-44.

41 For a recent discussion, see André Chastel, "La Notion de Patrimoine," Les Lieux de mémoire, ed., Pierre Nora, II (Paris, 1986).

42 Citations here from the monograph, Félicie d'Ayzac, Mémoire sur trente-deux statues symboliques observées dans la haute partie des tourelles de Saint-Denys. Precédé d'une Introduction traitant du Symbolisme dans l'Architecture par M. César Daly (Paris, 1847).

43 Ayzac, Mémoire sur trente-deux statues, 30, 32, 38.

44 Emile Mâle, L'Art religieux du XIIIe siècle, $7^{\text {th }}$ edn (Paris, 1931), 43, asserted that Bernard's condemnation made nugatory the symbolic reading of Félicie d'Ayzac. Bernard's deployment of a topos criticizing hybrids from Horace's Ars Poetica, pointed out by John Gage, does not, however, address the question of meaning. See Gage, "Horatian Reminiscences in Two Twelfth-Century Art Critics," Journal of the Warburg and Courtauld Institutes, XXXV (1973), 359-60.

45 Ayzac, Mémoire sur trente-deux statues, 30.

46 Ayzac, Mémoire sur trente-deux statues, 181-82.

47 Ayzac, Mémoire sur trente-deux statues, 115.

48 William Mason, trans., Sir Joshua Reynolds, annot., The Art of Painting of Charles Alphonse du Fresnoy (Dublin, 1783), 46.

49 As instanced recently in imagery of the National Gallery exhibition, L'Ingénieuse machine humaine: Quatre siècles d'art et d'anatomie (Ottawa, 1996).

50 A.-N. Didron, Iconographie chrétienne, Histoire de Dieu (Paris, 1843).

51 Félicie d'Ayzac, Symbolique des pierres précieuses, ou Tropologie des gemmes (Paris, 1846). Didron's criticism, as in the Annales, is included in a note on pp. 18-19.

52 Ayzac, Symbolique des pierres précieuses, 225.

53 Frances Yates, The Occult Philosophy in the Elizabethan Age (London, 1983), 2. 
54 Yates, The Occult Philosophy, 9-11.

55 Félicie d'Ayzac, Histoire de l'Abbaye de Saint-Denis en France (Paris, 1860-61); idem. Des Eglises de l'Italie et celles de la France, de l'Angleterre et de l'Allemagne ... (Paris, 1853); idem, Les Statues du porche septentrional de Chartres ou Explication de la Présence des Statues de la Liberté, de la Santé, de la Beauté, de la Volupté, de l'Honneur, sur les basiliques chrétiennes et Les Quatre animaux mystiques, attributs des Quatre Evangelistes (Paris, 1849). The encyclopaedic Zoologie mystique was not completed as planned, but published in part posthumously as "De la Zoologie composite ... ," Revue de l'art chrétien (1886), 13-36. Separate publications on the iconography of the elephant (1853), dragon (1864), weasel (1878) and bull (1880) stemmed from this project.

56 For the monograph's partial publication, see Catherine Brisac and J.-M. Léniaud, "Adolphe-Napoléon Didron ou les media au service de l'art chrétien," Revue de l'art, LXXVII (1987), 35. Félicie d'Ayzac states that he shared his findings with other archaeologists (Ayzac, Les Statues du porche septentrional, 4); they were also published in the Annales archéologiques (1847-49).

57 As cited in Ayzac, Les Statues du porche septentrional, 9.

58 Fraisse, Muse de la Raison, 211.

59 Fraisse, Muse de la Raison, 207.

60 Emile Mâle, L'Art religieux du XIIIe siècle en France: Etude sur l'iconographie du moyen age et sur ses sources d'inspiration, $7^{\text {th }}$ edn (Paris, 1931). References to Félicie d'Ayzac on pp. 21, 36, 47, 48.

61 Clara Thomas, Love and Work Enough: The Life of Anna Jameson (Toronto, 1967), 30, 50, 68-69, 77, 83.

62 Principal biographical sources for Anna Jameson are her CommonPlace Book of Thoughts, Memories, and Fancies (London, 1854); Gerardine Macpherson, Memoirs of the Life of Anna Jameson (London, 1878); and the life by Professor Thomas.

63 Anna Jameson, A Common-Place Book of Thoughts, Memories, and Fancies, new edn (London, 1877), 101.

64 Valerie Sanders, The Private Lives of Victorian Women: Autobiography in Nineteenth-Century England (New York and London, 1989), $11,15-18$.

65 Mrs. Jameson, The Diary of an Ennuyée (Boston, 1865). References to this edition are included in the text of this article.

66 See, for example, Ruskin's comparison of Jameson to his family's servant Ann Strachan, claiming the former "knows as much of art as the cat"; Harold I. Shapiro, ed., Ruskin in Italy (Oxford, 1972), 215-16; and Francis Haskell's dismissal of her over a century later as a "one-time governess [and] jilted wife", repeating Ruskin's allegation of her ignorance of art; Francis Haskell, Rediscoveries in Art (London, 1976), 106.

67 Recent scholarship has not settled the question. Evelina Borea, Domenichino (Rome, 1965), 175, considers the picture a St Cecilia. Richard E. Spear, Domenichino, 2 vols (New Haven and London, 1982), I, 191-92 titles it The "Cumaean" Sibyl.

68 Judith Johnston, Anna Jameson: Victorian, Feminist, Woman of Letters (Aldershot, Hants, 1997), 6.

69 Jameson, Visits and Sketches at Home and Abroad, $3^{\text {rd }}$ edn, 2 vols (London, 1839), 1, 8.

70 Jameson, Collection of Pictures of W.G. Coesvelt, Esq. of London With an Introduction by Mrs. Jameson (London, 1834).
71 Jameson, Collection of Pictures of W.G. Coesvelt, v.

72 G.F. Waagen, Peter Paul Rubens, His Life and Genius, ed., Anna Jameson, trans., Robert R. Noel, (London, 1840). In addition to her introduction, Jameson annotated Waagen's text.

73 Waagen/Jameson, Peter Paul Rubens, see especially xi-xiii.

74 [Francis Jeffrey], "Review of Archibald Alison, Essays on the Nature and Principles of Taste, 2 vols, Edinburgh, 1811," The Edinburgh Review, XVIII (May 1811), 1-46. I am indebted to a recent discussion of Jeffrey's aesthetics in Kay Dian Kriz, The Idea of the English Landscape Painter (New Haven and London, 1997), 87-90.

75 Jameson. In its original title, The Poetry of Sacred and Legendary Art, 2 vols (London, 1848). Here quoted from a later edition, Sacred and Legendary Art (London, 1905), I, vii.

76 The essays were republished as Anna Jameson, Memoirs of the Early Italian Painters, and of the Progress of Painting in Italy, from Cimabue to Bassano, 2 vols in 1 (London, 1845).

77 Laurie Kane Lew, "Cultural Anxiery in Anna Jameson's Art Criticism," Studies in English Literature, XXXVI (1996), 829-56. For the classification of "brows", its connection with phrenology and the schema's racist applications, see Lawrence W. Levine, Highbrow/Lowbrow: The Emergence of Cultural Hierarchy in America (Cambridge, Mass., and London, 1988), esp. 221-23.

78 Anna Jameson, Companion to the Most Celebrated Private Galleries of Art in London (London, 1844), 386.

79 Sequels to Sacred and Legendary Art are Legends of the Monastic Orders, as Represented in the Fine Arts (London, 1850); Legends of the Madonna, as Represented in the Fine Arts (London, 1852); and The History of Our Lord as Exemplified in Works of Art, completed by Lady Eastlake, 2 vols (London, 1864).

80 Roelof van Straten, An Introduction to Iconography, trans., Patricia de Man (Yverdon, Switz., 1993), 110.

81 Balayé, in Staël, Corinne, 23; Stä̈l, Corinne, 582.

82 Incised on marble pedestal. National Portrait Gallery: Early Victorian Portraits, 2 vols (London, 1973), I: Text, Richard Ormond, cat. no. 689.

83 Paul Rabinow, ed., Donald F. Bouchard and Sherry Simon, trans., The Foucault Reader (New York, 1984), 80; originally, "Nietzsche, la généalogie, l'histoire," Hommage à Jean Hyppolite (Paris, 1971).

84 Pierre Bourdieu, "The Genesis of the Concepts of Habitus and of Field," Channa Newman, trans., Sociocriticism, II (Dec. 1985), 11-24. Panofsky's Abbot Suger on the Abbey Church of St. Denis and its Art Treasures (1946) and Gothic Architecture and Scholasticism (1951) were translated by Bourdieu in Architecture gothique et pensée scholastique (Paris, 1967).

85 Jameson, Sacred and Legendary Art, I, 76; II, 753.

86 As in Jesse M. Gellrich, "The Art of the Tongue: Illuminating Speech and Writing in Later Medieval Manuscripts," Virtue and Vice: The Personifications in the Index of Christian Art, ed., Colum Hourihane (Princeton, 2000).

87 Foucault, "Nietzsche, Genealogy, History," 85.

88 Mâle, L'Art religieux, v.

89 Mâle, L'Art religieux, 21, n. 4.

90 Letter to author, 11 April 1975.

91 Letter to author, 20 Jan. 2000. 